UNIVERSIDADE DE SÃO PAULO

FACULDADE DE MEDICINA DE RIBEIRÃO PRETO

DEPARTAMENTO DE GENÉTICA

PROGRAMA DE PÓS-GRADUAÇÃO EM GENÉTICA

DINÂMICA REPRODUTIVA E INFLUÊNCIA DAS ÁREAS DE CONGREGAÇÃO DE ZANGÕES NA AFRICANIZAÇÃO DE Apis mellifera (APIDAE: APINI) NO BRASIL

OMAR ARVEY MARTÍNEZ CARANTÓN

RIBEIRÃO PRETO

2006 
UNIVERSIDADE DE SÃO PAULO

FACULDADE DE MEDICINA DE RIBEIRÃO PRETO

DEPARTAMENTO DE GENÉTICA

PROGRAMA DE PÓS-GRADUAÇÃO EM GENÉTICA

\section{DINÂMICA REPRODUTIVA E INFLUÊNCIA DAS ÁREAS DE CONGREGAÇÃO DE ZANGÕES NA AFRICANIZAÇÃO DE Apis mellifera (APIDAE: APINI) NO BRASIL}

OMAR A. MARTÍNEZ CARANTÓN

Dissertação de Mestrado apresentada à Faculdade de Medicina de Ribeirão Preto da Universidade de São Paulo para obtenção do título de Mestre em Ciências - Área de concentração: Genética.

RIBEIRÃO PRETO

2006 
UNIVERSIDADE DE SÃO PAULO

FACULDADE DE MEDICINA DE RIBEIRÃO PRETO

DEPARTAMENTO DE GENÉTICA

PROGRAMA DE PÓS-GRADUAÇÃO EM GENÉTICA

\section{DINÂMICA REPRODUTIVA E INFLUÊNCIA DAS ÁREAS DE CONGREGAÇÃO DE ZANGÕES NA AFRICANIZAÇÃO DE Apis mellifera (APIDAE: APINI) NO BRASIL}

OMAR A. MARTÍNEZ CARANTÓN

Dissertação de Mestrado apresentada à Faculdade de Medicina de Ribeirão Preto da Universidade de São Paulo para obtenção do título de Mestre em Ciências - Área de concentração: Genética.

Orientador: Prof. Dr. ADEMILSON ESPENCER EGEA SOARES

RIBEIRÃO PRETO 
FICHA CATALOGRÁFICA

Martínez, Omar Arvey Carantón

Dinâmica reprodutiva e influência das áreas de congregação de zangões na africanização de Apis mellifera (Apidae: Apini) no Brasil. Ribeirão Preto, 2006. 69 p:il; 30cm.

Dissertação apresentada à Faculdade de Medicina de Ribeirão PretoUSP. Área de concentração: Genética.

Orientador: Prof. Dr. Ademilson Espencer Egea Soares.

1. Apis mellifera 2. Africanização 3. Área de congregação de zangões 4 Reprodução 5 Comportamento de vôo, 
Data da Defesa:

BANCA EXAMINADORA

Prof. Dr.

Julgamento

Assinatura

Prof. Dr.

Julgamento

Assinatura

Prof. Dr.

Julgamento

Assinatura 
Dedico a toda minha família, em especial aos meus queridos Pais e irmão. 


\section{AGRADECIMENTOS}

Ao Prof. Dr. Ademilson Espencer Egea Soares. Uma pessoa que sempre me motivou durante este trabalho e em especial durante toda minha estadia no Brasil. Grande Professor e amigo.

À Universidade de São Paulo, campus de Ribeirão Preto, Faculdade de Medicina, departamento de Genética, especialmente ao Bloco A, por permitirem realizar meu trabalho de pesquisa, além de comporem um dos melhores laboratórios de pesquisa em abelhas encontrado em toda a América do Sul.

Aos Prof (s). Dr (s), Lionel Gonçalves, David De Jong, Klaus Hartfelder, Zilá Luz Paulino Simões e Márcia Bitondi, por todos estes anos de trabalho e contínuo aprendizado.

Às famílias Arévalo Niño, Naranjo Martínez, que sempre me apoiaram durante todo este tempo.

Aos meus colegas e grandes amigos, Geusa de Freitas, Paulo Emilio, Weyder Santana, Ivan Akatsu, por estes anos de amizade e bons momentos.

Aos meus colegas de laboratório e pesquisa em abelhas, Rogério, Tiago, Carlos, Gesline, Mônica, Alexandre, Francis, Aline, Ana Paula, Sergio, Michelle, Anete, Rodrigo, Karina, Vanessa, Camila, Ana Rita, Marina, Tita, Érika e todos aqueles que esqueço de citar.

À Marcela Aparecida Framartino Bezerra Laure, pela grande amizade que me ofereceu e por todos os bons momentos que compartilhamos juntos.

Ao técnico Jairo de Souza, por todos estes anos de trabalho e em especial pela grande amizade.

Às técnicas de laboratório Vera e Adriana, por toda a ajuda prestada durante todos estes anos.

Aos técnicos e grandes amigos, João José dos Santos, Adelino Penatti, Luiz Roberto Aguiar, Roberto Mazzuco. 
À Maria Aparecida Oliveira Silva Elias, Susie Adriana Penha Nalon e Cleusa Sueli Mazucato da Motta, por toda a ajuda que sempre me brindaram, respeito e em especial pelo carinho que tenho por elas.

À Andrea Milena, Fredy Salazar, por essa grande amizade e por toda a ajuda e motivação.

À doutoranda Monica Mayorano, pessoa que sempre me ajudou e me aconselho durante todos estes anos.

À Sandra Lucia Sarmiento, por tudo, absolutamente tudo, pela amizade, carinho, compreensão, e contínua motivação durante todos estes anos.

Aos meus colegas e grandes amigos, Geusa de Freitas e Weyder Santana, por estes anos de amizade e bons momentos. Além de toda a ajuda prestada durante a elaboração e redação deste manuscrito.

E quase por último, mas não menos importante e de modo muito especial, Umberto Moreno, pela grande amizade que durante todos estes anos de estudo e trabalho que temos compartilhado, pelos inúmeros conselhos durante a realização deste trabalho e pela contínua motivação profissional.

Às instituições CAPES e CNPQ, pela ajuda financeira oferecida na realização deste trabalho.

À todas as pessoas que de alguma forma me esqueço de citar nestes agradecimentos e que fizeram parte deste trabalho. 


\section{CONTEÚDO}

\section{LISTA DE FIGURAS}

LISTA DE TABELAS

RESUMO

ABSTRACT

1. INTRODUÇÃO 9

2. OBJETIVOS 11

2.1 OBJETIVO GERAL 11

2.2 OBJETIVOS ESPECÍFICOS 11

3. REVISÃO BIBLIOGRÁFICA 12

3.1 COMPORTAMENTO REPRODUTIVO 12

3.2 ÁREAS DE CONGREGAÇÃO DE ZANGÕES 19

3.3 PROCESSO DE AFRICANIZAÇÃO 24

4. MATERIAL E MÉTODOS 30

4.1 ANÁLISE DA ATIVIDADE DE VÔO 30

4.2 ANÁLISE DAS ÁREAS DE CONGREGAÇÃO DE ZANGÕES (ACZ) 33

4.3 COLETA DE ZANGÕES NAS ACZ 35

5. RESULTADOS 38

5.1 COMPORTAMENTO DE VÔO DAS RAINHAS AFRICANIZADAS E RAINHAS CARNICAS 38

5.2 COMPORTAMENTO DE VÔO DE ZANGÕES AFRICANIZADOS E ZANGÕES CARNICOS 42

5.3 ANÁLISES DAS ÁREAS DE CONGREGAÇÃO DE ZANGÕES 43

5.4 COLETA DE ZANGÕES NAS ACZ 49

6. DISCUSSÃO 50

7. CONCLUSÕES 54

REFERENCIAS BIBLIOGRÁFICAS 57 


\section{LISTA DE FIGURAS}

Figura 1 - Representação da imagem do radar durante o horário de vôo dos zangões e sem nenhum tipo de estímulo sensorial (modificado de Loper, 1993). 16

Figura 2 - Representação da imagem do radar onde observa-se, após a exposição do feromônio, a distância e a direção de vôo dos zangões contra o vento (modificado de Loper, 1993).

Figura 3 - Dinâmica de dispersão das abelhas africanizadas nas Américas (modificado de Mistro et al., 2005). 28

Figura 4 - Desenho esquemático do vestíbulo instalado na entrada dos núcleos e mini-recrias (modificado de Tozetto, 1997). 31

Figura 5 - Armadilha aérea utilizada para capturar os zangões nas ACZ: 1) gaiola contendo uma rainha fecundada e algumas operárias; 2) fio de nylon grosso (0,9 $\mathrm{mm})$; 3) fio de nylon fino (0,2 $\mathrm{mm})$; 4) arame (1,5 mm); 5) tubo de borracha; 6) rede de filó branca. 36

Figura 6 - Metodologia usada nas observações e nas coletas de zangões nas ACZ.37

Figura 7 - Principais parâmetros do comportamento de vôo de rainhas africanizadas e carnicas de Apis mellifera. 40

Figura 8 - Horário da tarde no qual as rainhas africanizadas e carnicas realizaram o vôo de acasalamento. 41

Figura 9 - Horário de pico de atividade de vôo dos zangões africanizados $e$ carnicos. 42

Figura 10 - Imagem de satélite do campus da USP de Ribeirão Preto e os locais onde foram analisadas as ACZ (Fonte: Google Earth). 43 
Figura 11 - Número médio de zangões observados seguindo a isca nas diferentes ACZ.

Figura 12 - Resultados obtidos nos diferentes pontos analisados, durante cada intervalo de observação (20 min.), iniciando às 14:00 h e terminando às 17:00 h. As barras representam o número de zangões observados; as linhas indicam a velocidade do vento. As correlações destes parâmetros estão indicadas por " $r$ ". _46 Figura 13 - Resultados obtidos nos diferentes pontos analisados, durante cada intervalo de observação (20 min.), iniciando às 14:00 h e terminando às 17:00 h. As barras representam o número de zangões observados; as linhas indicam a Intensidade luminosa (X100 Lux). As correlações destes parâmetros estão indicadas por " $r$ ". 47

Figura 14 - Alguns registros fotográficos e imagens das diferentes áreas de congregação de zangões. 48 


\section{LISTA DE TABELAS}

Tabela 1 - Resultados obtidos durante o comportamento de vôo das rainhas carnicas e européias em função dos determinados comportamentos. 


\section{RESUMO}

\section{MARTINEZ. O. A. Dinâmica reprodutiva e influência das áreas de congregação de zangões na Africanização de Apis mellifera (APIDAE: APINI) no Brasil.} 2006. 73p. Dissertação de Mestrado - Faculdade de Medicina de Ribeirão Preto, Universidade de São Paulo, Ribeirão Preto, Brasil

A introdução de 33 rainhas africanas (Apis mellifera scutellata) em 1956, com o objetivo de iniciar um programa de seleção e melhoramento genético no Brasil, e a posterior enxameação de algumas destas rainhas, deu inicio ao processo de Africanização, originando o poli-híbrido, denominado, "Abelha africanizada". Este processo envolveu uma série de fatores biológicos e ambientais, cujas interações não são suficientemente claras. Os acasalamentos em abelhas melíferas ocorrem em sítios denominados como Áreas de Congregação de Zangões (ACZ), estes locais têm sido bem estudados em abelhas européias, porém, pouco pesquisados em abelhas africanizadas. Assim, é mister a necessidade de desenvolver novos estudos sobre o comportamento reprodutivo destas subespécies, que contribuíram para a rápida expansão das abelhas africanizadas nas Américas. Foram observados os comportamentos de vôos de 10 rainhas (Apis mellifera carnica e Apis mellifera africanizada) e de 126 e 146 zangões de cada raça, respectivamente. Observou-se 6 pontos, localizados no campus da USP de Ribeirão Preto, os quais poderiam ter uma maior concentração de zangões em vôo. Estes pontos foram analisados por meio de uma rainha fecundada presa a um balão preenchido com gás Helio e determinadas características ambientais. Todas as rainhas retornnaram ao núcleo com a marca de acasalamento e iniciaram o processo de postura. Os dados revelaram que não existem diferenças significativas $(\alpha=0,05 \%)$ ao compararmos: A idade da rainha no seu primeiro vôo ( $T=123$ : $\mathrm{P}=0,185)$; a idade da rainha no vôo do acasalamento $(t=1,721 ; \mathrm{P}=0,104)$; o numero de vôos que cada rainha realizou $(\mathrm{T}=79,5 ; \mathrm{P}=0,789)$; a duração do vôo de acasalamento $(t=1,065$; $\mathrm{P}=0,303)$; a temperatura no dia do vôo de acasalamento $(t=0,263 ; \mathrm{P}=0,796)$ e o horário do dia no qual ocorrem os vôos de acasalamento $(t=0,0 ; \mathrm{P}=1,0)$. A atividade de vôo dos zangões carnicos nunca precedeu o horário as $14: 15$ e 14:30h para zangões carnicos e africanizados, respectivamente, confirmando que não existem diferenças significativas no período do dia em que estes realizam seus vôos $(\mathrm{t}=-3,11 \mathrm{E}-015 ; \mathrm{P}=1,000)$. Dos 6 pontos observados, somente um ponto não atraiu zangões à isca. Não foram encontrados diferenças significativas entre as diferentes ACZ $(\mathrm{P}=0,109)$. Ao analisar a velocidade do vento $(\mathrm{m} / \mathrm{s})$, a analise de variância encontrou diferenças significativas entre as diferentes $\operatorname{ACZ}(\mathrm{P}=<0,001)$, porém não influenciando a presença de zangões na isca. Dados coletados neste experimento revelaram que os zangões freqüentam estas áreas durante condições de vento superiores a 4 $\mathrm{m} / \mathrm{s}$, e em algumas ocasiões com ventos de $8.1 \mathrm{~m} / \mathrm{s}$. Também foi observado que os zangões realizam seus vôos de acasalamento em dias nublados e com pouca luminosidade. Não existiu uma preferência, pelos zangões, por determinadas ACZ, constatando-se que o ambiente oferece muitos espaços abertos típicos de ACZ, garantindo e facilitando o acasalamento destas abelhas.

Palavras-chave: Africanização, comportamento de vôo, áreas de congregação de zangões, reprodução. 


\begin{abstract}
MARTINEZ. O. A. Reproductive dynamics and the influence of drone congregation áreas on the Africanization process of Apis mellifera (APIDAE: APINI) in Brazil. 2006. 73p. Dissertação de Mestrado - Faculdade de Medicina de Ribeirão Preto, Universidade de São Paulo, Ribeirão Preto, Brazil
\end{abstract}

The introduction of 33 African queens (Apis mellifera scutellata) in 1956, with the objective to initiate a program of selection and genetic improvement in Brazil, and with the posterior swarming of some of these queens, the Africanization process started. It gave origin to its polihybrid called "Africanized Bee". This process involved a series of biological and environmental factors, which interactions are not yet very clear. The mating process in honey bees occur in sites named Drone congregation Areas (DCAs), these places has been well studied in European bees, however, the research carried out and developed with Africanized bees has been few. Hence, there is a need to formulate and to develop new studies that better explain the reproductive behavior of these subspecies, determining or not the possible behavioral and reproductive characteristics, that had contributed for the fast expansion of the Africanized bees in the Americas. The flight behaviors of 10 queens (Apis mellifera carnica and Apis mellifera africanized) and of 126 and 146 drones were observed respectively. 6 different locations in the Ribeirão Preto campus of the USP were observed, in which a high concentration of drones in the air was assumed, these points were analyzed by means of a caged mated queen hanged in a balloon filled with gas Helio and determined according to environmental characteristics. All the queens came back to its hive with the mating mark and initiated the laying process normally. The data disclose that there are not significant differences $(\alpha=0.05 \%)$ when matching: The age of the queen at first flight $(t=1,721 ; \mathrm{P}=0,104)$; the number of flights that each queen carried out $(\mathrm{T}=79,5 ; \mathrm{P}=0,789)$; the time of the mating fly $(t=1,065 ; \mathrm{P}=0,303)$; Temperature in the day of the mating $(t=0,263$; $\mathrm{P}=0,796)$ and the time of the day the mating flights are carried out $(t=0,0 ; \mathrm{P}=1,0)$. The activity of flight for Carnic drones never started before 14:15 and 14:30 for Africanized drones confirming that there is not significant differences in the period of the day they perform their flights $(t=-3,11 \mathrm{E}-015 ; \mathrm{P}=1,000)$. Out of the 6 observed locations, one of them did not attract drones to the lure, when the data (the approximate number of drones in the different DCAs) were analyzed statistically, the ANOVA did not find significant differences between the different DCAs $(\mathrm{P}=0,109)$. When analyzing the speed of the wind $(\mathrm{m} / \mathrm{s})$, the ANOVA found significant differences between the different DCAs $(\mathrm{P}=<0,001)$, however not influencing the presence of drones in the lure. Data collected in this experiment show that the drones visit these areas during conditions of wind over $4 \mathrm{~m} / \mathrm{s}$, and in some occasions with winds of $8.1 \mathrm{~m} / \mathrm{s}$ with approximately 30 drones reaching the lure, it was also observed in this experiment that the drones perform mating flights, even in cloudy days and with low luminosity. There was not observed a preference for determined DCAs, even more, the nature offers a lot of wide open spaces of DCAs guaranteeing and facilitating the mating of these bees in various places.

Key-Words: Africanization, behavior of flight, Drone congregation areas, reproduction. 


\section{INTRODUÇÃO}

A baixa produtividade das abelhas européias (Apis mellifera ligustica, Apis mellifera carnica, Apis mellifera caucasica e Apis mellifera mellifera) no Brasil motivou a importação de linhagens mais produtivas e adaptadas ao clima tropical. Em 1956 foram introduzidas no Brasil 33 rainhas africanas (Apis mellifera scutellata) com o objetivo de iniciar um programa de seleção e melhoramento genético. Em 1957 enxamearam 26 destas colônias, dando origem ao processo de Africanização (Gonçalves, 1974; Gonçalves, 1992) no Brasil e na América com um todo.

Atualmente as abelhas africanizadas (poli-híbrido resultante do cruzamento das abelhas africanas com abelhas de origens européias) são encontradas em quase toda América do Sul (até o paralelo 33 Sul), América Central, e parte Sul da América do Norte (até o paralelo 33 Norte, aproximadamente). Este processo de africanização observado nas Américas em menos de 50 anos, devido a uma única espécie de inseto, é um dos processos mais rápidos e surpreendentes de invasão biológica já ocorrido e tendo sido objeto de numerosas pesquisas. Somente algumas regiões da América do Sul ainda possuem abelhas $100 \%$ de origem européia, isto se deve principalmente a algumas barreiras naturais e condições climáticas que tem impedido a chegada das abelhas africanizadas.

Este processo envolveu uma série de fatores biológicos e ambientais, cujas interações não são suficientemente claras. Nos últimos anos, o processo reprodutivo das abelhas Apis mellifera, foi objeto de estudo de muitos pesquisadores tentando, assim, conhecer a biologia reprodutiva, a genética e o processo de dispersão, bem como outros fatores biológicos. Segundo Teixeira (1992), existem diferenças no comportamento reprodutivo de abelhas africanizadas e de abelhas européias, 
apresentando diferentes horários nos vôos de acasalamento, tanto nos zangões como nas rainhas. Porém, segundo Cristino (2003), o horário do vôo de acasalamento não apresenta diferenças entre zangões destas subespécies.

Muitos trabalhos determinaram, por meio de análises de morfometria e geométria de asas o grau de africanização das populações de diferentes paises. Outras pesquisas têm confirmado estes resultados por meio de análises moleculares e usando uma nova metodologia de análise automática de imagens "ABIS", usado principalmente na identificação de espécies (Francoy et al., em publicação). Porém, na maioria dos paises da América do Sul e Central, existe uma maior contribuição de caracteres de origem africano.

Após 50 anos de Africanização, ainda se desconhece que fatores comportamentais destas subespécies de abelhas possibilitaram este processo. Devido à falta de conhecimento, houve a necessidade de formular e desenvolver novos estudos que verificassem as possíveis características comportamentais e reprodutivas destas subespécies, que contribuiriam para a rápida expansão das abelhas africanizadas nas Américas, com a conseqüente substituição dos genótipos europeus.

Os locais onde ocorrem os acasalamentos em abelhas melíferas são denominados como Áreas de Congregação de Zangões (ACZ), estes locais têm sido intensivamente estudados em abelhas européias, porém, pouco pesquisados e desenvolvidos em abelhas africanizadas. Após 50 anos de africanização no Brasil, somente o trabalho realizado por Cristino em 2003 abordou este tema.

O comportamento de vôo de zangões e rainhas pode ser usado como uma ferramenta importante e fundamental nos trabalhos relacionados as ACZ, pois estas áreas dependem fundamentalmente de tal comportamento de vôo. Posteriormente à análise no comportamento de vôo, pretendeu-se dar inicio ao monitoramento das ACZ, já que estes dados estão diretamente relacionados. Assim, propôs-se analisar os aspectos da dinâmica reprodutiva e a caracterização das áreas de congregação de zangões (ACZ), estudando o comportamento de vôo, manutenção e/ou periodicidade das ACZ. Os comportamentos de vôos de rainhas e zangões poderão indicar alguns possíveis isolamentos reprodutivos que interferem no processo de dispersão e africanização. 


\section{OBJETIVOS}

\subsection{OBJETIVO GERAL}

O objetivo principal deste projeto é determinar a dinâmica reprodutiva e a influência das áreas de congregação de Apis mellifera no processo de africanização das abelhas no Brasil. Para alcançar este objetivo foram planejados e desenvolvidos estudos de reprodução, comportamento e biologia em linhagens africanizadas e européias.

\subsection{OBJETIVOS ESPECÍFICOS}

* Estudar o comportamento de vôo de rainhas africanizadas Apis mellifera L. e de rainhas européias Apis mellifera carnica.

Estudar o comportamento de vôo de zangões africanizados Apis mellifera L. e de zangões europeus Apis mellifera carnica.

* Estudo e caracterização de locais onde possivelmente ocorre o acasalamento em abelhas Apis mellifera, locais considerados pela literatura como áreas de congregação de zangões (ACZ).

Determinar quais parâmetros poderão determinar ou influenciar o comportamento reprodutivo dos zangões africanizados nas ACZ.

* Determinar quais são as condições ambientais ótimas em que as abelhas africanizadas e carnicas (rainhas e zangões) realizam os vôos de acasalamento. 


\section{REVISÃO BIBLIOGRÁFICA}

\subsection{COMPORTAMENTO REPRODUTIVO}

Nas abelhas o sexo é determinado pelo fato dos indivíduos serem haplóides ou diplóides: Os embriões diplóides se desenvolvem de ovócitos fertilizados, tornando-se fêmeas; e os embriões que se desenvolvem de ovócitos não fertilizados, tornar-se-ão machos. $\mathrm{O}$ fato de determinada fêmea desenvolver-se ou não em uma forma reprodutiva, rainha, dependerá de como a larva for alimentada durante o desenvolvimento. Assim, uma rainha pode controlar a relação entre machos e fêmeas, regulando a proporção de ovócitos não fertilizados durante a postura. Em um sistema haplo-diplóide de determinação sexual, chamado de partenogênese arrenótoca, os ovócitos são produzidos por meiose na rainha e os espermatozóides são produzidos por mitose no macho. Assim, ovócitos fertilizados (32 cromossomos) terão um número cromossômico diplóide e ovócitos não fertilizados terão o número haplóide (16 cromossomos) (Snustad \& Simmons, 2001).

O primeiro experimento a respeito de um provável acasalamento em abelhas foi realizado por Huber (1792), mencionando que as rainhas só produziam operárias quando estas podiam realizar vôos fora da colmeia, descrevendo também "a marca de acasalamento" como uma parte do aparato reprodutor do zangão que ficava aderido a câmara do ferrão na rainha (apud Koeniger, 1986).

Nas abelhas melíferas (Apis mellifera.) o comportamento reprodutivo é caracterizado por muitos fenômenos como: um grande desvio de sexo para os machos (Seeley, 1985; Winston, 1987; Moritz \& Southwick, 1992); machos obrigatoriamente monógamos, pois os zangões morrem logo após do acasalamento; extrema poliandria das rainhas, acasalando-se com 10 - 50 zangões (Palmer \& 
Oldroyd, 2000); locais de acasalamento que são mantidos por mais de 50 anos (JeanProst, 1957; Tribe, 1982); e cópula durante o vôo (Koeniger \& Koeniger, 1991 apud Koeniger et al., 2005a).

Logo após a emergência da rainha, pode-se observá-la caminhando sobre a área de cria da colmeia, destruindo outras células reais e/ou lutando com outra rainha virgem, caso ocorram na colônia. Entre 3 e 5 dias após emergir, a rainha virgem inicia um comportamento específico dentro da colônia, expondo a câmara do ferrão e vibrando o abdome, sinalizando assim sua presença. $\mathrm{O}$ primeiro vôo das rainhas virgens ocorre usualmente entre 5 e 6 dias após o nascimento, quando a atividade das glândulas exócrinas, das células neurosecretoras e os altos títulos de vitelogenina são indicativos da maturidade sexual da rainha. Esta apresentará comportamento específico neste período, sendo atraída pela luminosidade da entrada da colmeia, assim, localizando a saída da colônia e realizando os primeiros vôos de orientação os quais podem variar de 2 a 5 minutos. Posteriormente a rainha iniciará os vôos de acasalamento (Koeniger, 1986).

Em 1992, Teixeira observou que rainhas africanizadas e rainhas européias (Apis mellifera ligustica) realizaram no máximo três vôos de orientação, sendo que a maioria apresentou um ou dois vôos. Estes vôos de orientação ocorrem, em rainhas européias, em um período do dia anterior as 15:00h em $68 \%$ das vezes, enquanto que, em rainhas africanizadas, somente 38\% das rainhas realizam este vôo neste período. Igualmente foi observada uma diferença no horário dos vôos de acasalamento, enquanto $80 \%$ das rainhas européias realizam seus vôos de acasalamento antes das 15:00h, apenas $25 \%$ das rainhas africanizadas se acasalam neste horário. A média de idade das rainhas que realizam os vôos de acasalamento variou de $9 \pm 2,10$ dias para rainhas européias e 8,76 $\pm 1,84$ para as rainhas africanizadas. Segundo esta mesma autora, a maioria das rainhas africanizadas, $82 \%$ destas, acasalaram no primeiro vôo, não realizando mais que dois vôos; já $65 \%$ das rainhas européias realizam mais de dois vôos, a maioria das rainhas acasaladas durante este experimento retornou do respectivo vôo com a marca de acasalamento.

Pesquisas realizadas por Tarpy \& Page (2001) observaram que a duração média dos vôos de acasalamento nas rainhas foi de 24,2 $\pm 9,21$ minutos. Nestes vôos 
as rainhas efetivamente se acasalaram com 4,6 $\pm 3,67$ machos, não encontrando uma correlação direta entre o número de acasalamentos e a duração destes vôos.

Se os múltiplos acasalamentos são adaptações e têm sido moldados através da seleção natural, poderia-se supor que as rainhas de Apis mellifera tenderiam a otimizar seu comportamento, minimizando o número de vôos de acasalamento e maximizando o número de indivíduos com os quais se acasala. Dependendo do sucesso em seus vôos de acasalamento prévios, a rainha poderia decidir entre um ou mais vôos de acasalamento antes de dar início à oviposição. Segundo Schlüns et al. (2005), quando rainhas de Apis mellifera carnica foram restringidas a um único vôo de acasalamento, estas se acasalaram com significativamente menos zangões em comparação a rainhas com um número irrestrito de vôos. Isto suporta a hipótese que rainhas de Apis mellifera, tem um determinado controle comportamental sobre seus vôos de acasalamento, além disto, rainhas que se acasalaram mais vezes possuíam, freqüentemente, mais espermatozóides na espermateca. Porém, as rainhas têm que acasalar com vários zangões para garantir que ovolume da espermateca seja todo preenchido, possivelmente indicando que a limitação do sêmen seja uma provável causa para a evolução extrema da poliandria nestas abelhas.

Os aspectos genéticos da espermatogênese em zangões em desenvolvimento são conhecidos. Em zangões de 3 a 8 dias após a emergência, os espermatozóides iniciam a migração dos testículos para as vesículas seminíferas, onde ficam alojados por alguns dias até completar sua maturidade. A produção de muco pelas glândulas acessórias inicia-se somente após a emergência do inseto e é completada quando o indivíduo está com 6 a 7 dias de vida. A maioria dos zangões realiza seus primeiros vôos com uma idade de 6 a 8 dias, podendo ocorrer entre 4 e 14 dias de vida. Normalmente os vôos são realizados no período da tarde entre as 13:00 e as 16:00h do dia. Os tempos destes vôos dependem do fotoperíodo, contudo tais diferenças também podem ser resultado de variações climáticas e da própia subespécie das abelhas. A duração do primeiro vôo varia entre 6 e 16 minutos e geralmente é conhecido como vôo de orientação; vôos de acasalamento variam de 25 a 57 minutos e são realizados principalmente por zangões com uma idade superior a 12 dias, já que somente depois desta idade os espermatozóides estão completamente maduros (Koeniger, 1986). 
Teixeira (1992) menciona que zangões europeus realizam seus vôos mais cedo que zangões africanizados, apresentando o maior fluxo de zangões europeus no horário entre 14:00 e 15:00h enquanto os zangões africanizados são observados entre 15:00 e 16:00h, horário que coincide com o pico de vôo das rainhas européias e africanizadas analisadas nesse trabalho. Já Cristino (2003) não encontrou diferenças significativas nos horários dos vôos de zangões europeus (Apis mellifera ligustica) e africanizados, observando que $60 \%$ dos zangões europeus e que $73 \%$ de zangões africanizados realizam seus vôos principalmente durante o intervalo da tarde entre 14:00 e 15:00 h.

O acasalamento ocorre em vôo livre quando a rainha tem ao redor de 5 e 10 dia de idade, acasalando-se, em média, com 7 a 17 machos diferentes. Cada macho se acasala uma única vez, depositando 6 a 10 milhões de espermatozóides no oviduto meio da rainha, posteriormente morrendo. Assim, a rainha retorna à colônia após o vôo de acasalamento com 4 a 7 milhões de espermatozóides depositados pelos machos no oviduto. Estes espermatozóides migram, na rainha, por processos ativos e passivos para o interior da espermateca (órgão de armazenamento do esperma) por um período de aproximadamente 40 horas após o acasalamento (Page \& Laidlaw, 1992).

Koeniger et al. (2005a) assomem que devido aos múltiplos acasalamentos haverá duas fases diferentes durante o vôo de acasalamento da rainha nas áreas de congregação de zangões (ACZ): na primeira fase a rainha voa rapidamente e mantêm uma certa altura, durante este processo a rainha está disponível e a corrida pela disputa do acasalamento por parte dos machos inicia; a segunda fase começa quando o zangão consegue segurar a rainha, iniciando a cópula, transferindo o esperma e perdendo a mobilidade. Nesta situação a rainha é momentaneamente bloqueada e sua velocidade de vôo pode ser reduzida. Os zangões em perseguição persistem na disputa e procuram melhorar sua posição dentro do grupo de competidores, comumente chamado de cometa. A cópula em Apis mellifera dura menos de 2 segundos

A distância na qual um inseto pode responder a um estímulo sensorial (feromônio) de um outro inseto da mesma espécie tem sido tema de muitas 
pesquisas. Loper et al. (1993) com a ajuda do monitoramento por radar registrou o comportamento dos zangões de Apis mellifera para estes estímulos sensoriais. Nessa pesquisa foram utilizados $10 \mathrm{mg}$ de feromônio sintético (9-ODA) ácido-9-oxi-trans2-decenóico, quantidade equivalente a 100 vezes o feromônio que uma única rainha pode emitir. Este feromônio foi aplicado a um feltro de lubrificação usado como isca e suspendido a uma altura aproximada de $6 \mathrm{~m}$ acima do solo, esta isca tinha um diâmetro de $0,8 \mathrm{~cm}$ (aproximadamente $25 \mathrm{~mm}^{2}$ de superfície). No mesmo trabalho também foi utilizada uma rainha virgem como isca na ACZ. Todos os dados foram registrados antes, durante e após a exposição das diferentes iscas, relevando que:

- O vôo dos zangões antes da exposição da isca foi amplamente disperso e não foi organizado ou direcionado para nenhuma área em especial (ver figura 1). Este comportamento de vôo é distinto ao observado em outras áreas pelo mesmo autor Loper et al. 1992.

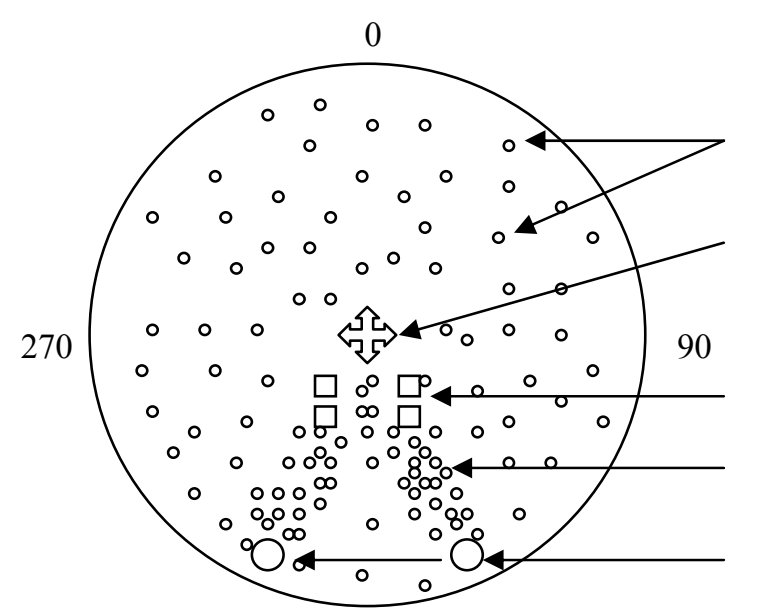

180
Zangões e algumas poucas operárias Radar

Apiário

Vôo das operárias

Fonte de água

\section{Figura 1 - Representação da imagem do radar durante o horário de vôo dos zangões e sem nenhum tipo de estímulo sensorial (modificado de Loper, 1993).}

- Uma vez exposta a rainha ou a isca com feromônio, formou-se uma concentração de zangões a favor do vento, formando um aglomerado de zangões próximos a isca. Estes zangões se aproximam contra o vento, procurando a fonte de feromônio, após chegarem perto da isca reagem por estímulos visuais. Considerando o vento como um fator responsável pela 
distribuição do feromônio em uma determinada área, estes zangões podem ser vistos e ouvidos próximos da fonte de odor ou da rainha exposta, como podese observar na figura 2.

- O radar mostrou o grupo de zangões aumentando em comprimento e que se estende a favor do vento (ver figura 2).

- Após a isca ser removida do local, observa-se que os zangões voam em diferentes direções, o autor descreve estas vias como vias de retorno para as respectivas colmeias.

Finalmente, verificou-se que os zangões reagem aos odores de uma única rainha por até $400 \mathrm{~m}$ e de uma fonte sintética de odor por até $800 \mathrm{~m}$ distante desta fonte do odor contra ao vento $(10-14 \mathrm{~km} / \mathrm{h})$. Dados similares foram observados em uma área diferente pelo mesmo autor, porém os zangões responderam a uma distância de $530 \mathrm{~m}$ da fonte sintética de odor, com vento a $14 \mathrm{~km} / \mathrm{h}$ (ver figura 2).

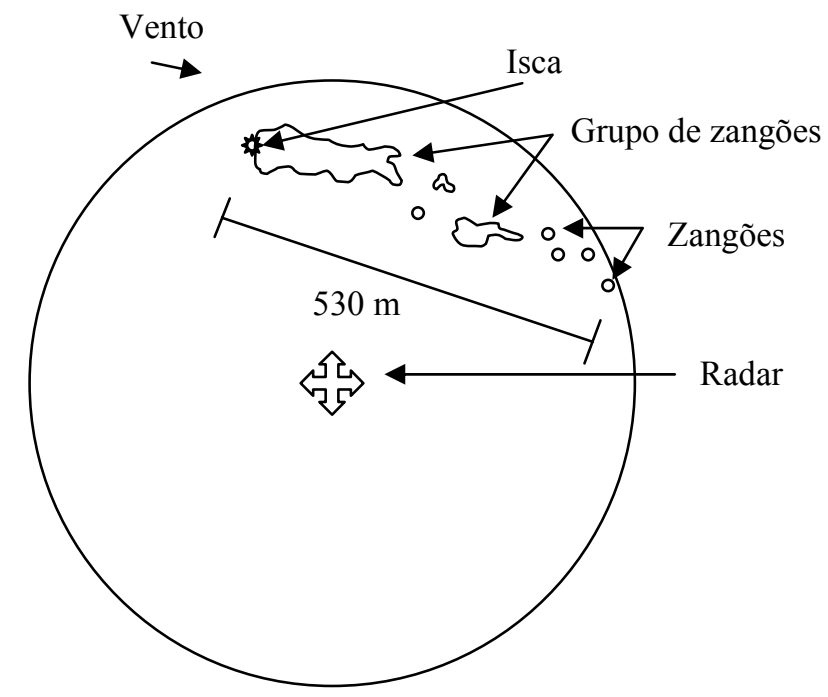

Figura 2 - Representação da imagem do radar onde observa-se, após a exposição do feromônio, a distância e a direção de vôo dos zangões contra o vento (modificado de Loper, 1993).

Rainhas e zangões sempre deixam suas colmeias para se acasalar, isto aumenta o risco da colmeia perder sua única rainha, a qual é muito sensível a condições ambientais (Koeniger, 1986). Condições com vento inferior a $19 \mathrm{~km} / \mathrm{h}$, temperatura superior a $20{ }^{\circ} \mathrm{C}$ e pouca nebulosidade diminuem este risco. $\mathrm{O}$ vôo da rainha ocorre geralmente nas horas mais quentes do dia, comportamento similar 
observado nos zangões, porém estes indivíduos podem também voar sob condições diferentes (Koniger, 1988).

As distâncias de vôos de rainhas e zangões não foi observada diretamente, porém alguns pesquisadores (Ruttner \& Ruttner, 1972) têm inferido estas distâncias usando marcadores genéticos e observaram que: A distância média entre o apiário e a área de acasalamento foi superior a $2 \mathrm{~km}$, apresentando uma distância máxima de 5 $\mathrm{km}$ e sendo que o raio de vôo dos zangões está entorno de $6 \mathrm{~km}$, preferencialmente com vôos de $5 \mathrm{~km}$.

Em 1955, Peer estabeleceu um apiário experimental em uma região livre de abelhas em uma área de 35 milhas $(64.82 \mathrm{~km})$, este apiário foi estabelecido com o intuito de determinar a distância máxima na qual colmeias de abelhas podem ser separadas para obter sucesso no acasalamento controlado. A distância máxima na qual colmeias com rainhas virgens e com zangões se acasalaram foi de 10,1 milhas $(18,70 \mathrm{~km})$ e distâncias entre 12 e 14 milhas $(19,31$ e $22.53 \mathrm{~km})$ entre estas colmeias não apresentaram nenhum tipo de acasalamento (Peer, 1957). Este mesmo autor observou que a porcentagem de rainhas virgens que iniciaram a postura diminuiu em relação a distância entre as colmeias, assim colmeias separadas a 3,8, 6,1, 8,0 e 10,1 milhas $(6,11,9,81,12,87$ e $16,25 \mathrm{~km})$ apresentaram $89,67,42$ e $25 \%$ de sucesso respectivamente, observando $100 \%$ de fecundação das rainhas quando as colmeias das rainhas virgens e dos zangões se encontravam no mesmo apiário.

Segundo Guler \& Alpay (2005), o ambiente e as condições climáticas tem grande efeito sobre características fisiológicas reprodutivas. Neste trabalho foi observado que $73,33 \pm 4,69 \%$ das rainhas acasaladas ocorreu durante um fluxo rico de néctar e pólen, com uma temperatura média de $21,52{ }^{\circ} \mathrm{C}$, uma porcentagem menor de rainhas foi vista se acasalando a temperaturas mais baixas. As rainhas acasaladas durante um bom fluxo de alimento e sob boas condições de temperatura, apresentaram uma maior quantidade de sêmen na espermateca, tais condições ambientais geralmente podem ser encontradas durante alguns meses do ano na Europa, sugerindo assim que atividades como troca de rainhas sejam realizadas durante estes períodos. 


\section{2 ÁREAS DE CONGREGAÇÃO DE ZANGÕES}

Logo após os zangões alcançarem sua maturidade sexual, se encontram aptos para se acasalar, então eles iniciam seus vôos de acasalamento. Muitos pesquisadores acreditavam que os zangões voavam para locais específicos, conhecidos como áreas de congregação de zangões (ACZ), pesquisadores têm localizado estas áreas pelo “droning”, som produzido pelo zangão ao voar, pelo uso de feromônio de rainha (9ODA, ácido-9-oxi-trans-2-decenóico) (Gary, 1963) ou por rainhas presas sob pipas, balões ou na extremidade de uma haste comprida (Zmarlicki \& Morse, 1963).

Em 1962, Gary descobreu algumas ACZ graças a um experimento que consistiu em elevar um balão cheio de gás hélio com uma rainha presa a este, para assim verificar o agrupamento de zangões em certas áreas. Os machos de abelhas $A$. mellifera formam grupos temporários durante a aproximação da isca, este grupo de machos foi denominado "Drone comets" (cometa de zangões) ou "mating comets" (cometa de acasalamento) e tem a característica de formar-se e desintegrar-se em alguns segundos.

As ACZ são definidas como um espaço aéreo, localizado entre 10 e 40 metros acima do solo, onde os zangões se reúnem e ficam sobrevoando pelos seus arredores. A área parece ter um extraordinário poder de atrair e manter os zangões juntos (Ruttner, 1966). Além disso, se acredita que os mesmos locais de congregação de zangões se mantém dia após dia, ano após ano e que isso ocorre independentemente da presença da rainha (Jean-Prost, 1958).

Segundo Loper et al. (1992) os vôos dos zangões fora da colmeia são realizados em rotas de vôo a uma altura aproximada de $21 \mathrm{~m}$, aumentando para aproximadamente $30 \mathrm{~m}$ nas ACZ, sendo observado o extremo de $55 \mathrm{~m}$ de altura de vôo por estes autores.

Na pesquisa realizada por Koeniger et al. (2005a), surpreendentemente não existe um contato físico ou uma disputa dos machos dentro do cometa, porém, estes ajustaram suas posições em relação aos seus vizinhos, ocupando ou defendendo alguma parcela do espaço. Os zangões que obterão sucesso no acasalamento voam através de um espaço seguro dentro de um área limitada (cerca de $20 \mathrm{~cm}$ de largura 
$X 10 \mathrm{~cm}$ de comprimento $X 10 \mathrm{~cm}$ de altura $=2000 \mathrm{~cm}^{3}$ ) localizado atrás e abaixo da rainha. Tais machos ficam pequenos períodos de tempo próximos à rainha, assim o tempo que se mantêm dentro do cometa é de um segundo ou menos, variando entre as diferentes subespécies de Apis mellifera. O tempo que cada indivíduo permanece depende, principalmente, da localização deste dentro do cometa e da probabilidade de se encontrar na posição adequada para capturar a rainha. Desta forma, a rainha somente se acasala com os zangões que são capazes de capturá-la. A seleção sexual poderia ter um impacto positivamente forte em uma rápida discriminação entre os zangões e a rainha, e uma ligeira resposta aos movimentos da rainha durante o acasalamento.

A média de zangões competindo pela rainha em um cometa varia entre as espécies, segundo Koeniger et al. (2005a) zangões de Apis koschevnikovi formam pequenos grupos entre 6 e 10 machos, em Apis mellifera o cometa pode conter em média 31 machos, o número de machos no cometa foi similar em Apis cerana e em Apis dorsata, 28 e 27 machos, respectivamente. Segundo estes mesmos autores, o número de zangões de Apis mellifera que estão visitando uma mesma ACZ variaram em torno de 11,750 $\pm 2,145$ indivíduos em uma região onde existem muitas colméias. Atualmente não se têm dados adicionais de populações silvestres ou de outras espécies de Apis. Assim, experimentos com iscas artificiais deveriam atrair milhares de zangões, porém o grupo de zangões relatados pelos autores acima nunca excedeu de 100 indivíduos. Gary (1963) verificou que números baixos por cometa, entre 100 e 300 zangões, eram visíveis quando uma ou mais iscas eram expostas simultaneamente, resultando em aproximadamente 60 indivíduos por isca.

Geralmente o tamanho e o tempo em que o cometa de zangões é formado, provavelmente esta relacionado com as correntes de vento e a velocidade do vento, além da habilidade dos zangões para localizar e voar em direção a fonte de feromônio (Loper et al. 1987).

Dados coletados pelo Cristino (2003) revelaram que até 95 zangões de Apis mellifera africanizada perseguiram uma rainha fecundada pressa a um balão com gás hélio e levantado a $15 \mathrm{~m}$ de altura, aproximadamente. 
O mecanismo de orientação dos zangões durante o vôo para a $\mathrm{ACZ}$ não é totalmente desconhecido. Zangões que foram transportados para uma nova área localizaram no seu primeiro vôo as ACZ e se encontraram com freqüências similares quando comparados com zangões que já faziam parte deste local. Tal fato descartou o fato do zangão possuir uma memória dos locais onde se encontram as $\mathrm{ACZ}$, ou de informações que o guiariam para realizar este primeiro voo (Ruttner, 1966; 1968 apud Koeniger et al. 2005b). Segundo estes autores, os zangões iniciam seus vôos de acasalamento sobrevoando depressões no horizonte, assim, a topografia do apiário pode ter um alto impacto na seleção dos zangões da ACZ.

Durante alguns anos, de 1963 a 1972, pesquisadores acompanharam o comportamento reprodutivo de sete $\mathrm{ACZ}$ em uma região de cerca de $70 \mathrm{~km}^{2}$, revelando uma complexa distribuição entre as ACZ. Zangões de cada apiário visitaram diferentes $\mathrm{ACZ}$ e cada $\mathrm{ACZ}$ teve uma alta mistura de zangões de apiários que estavam a $5 \mathrm{~km}$ de radio (Koeniger et al. 2005b). Pesquisas recentes apresentaram evidencias moleculares que revelam zangões de 238 colônias diferentes compartilhavam uma mesma ACZ (Baudry et al. 1998). Segundo estes autores os valores evidenciaram que devido ao alto número de colônias representadas em uma ACZ, garante-se o acasalamento de uma rainha com pelo menos um ou mais zangões não aparentados. Conseqüentemente, a média de parentesco entre o acasalamento de uma rainha específica com zangões provenientes da sua estrutura familiar, ou aparentados é muito baixa. Assim, a poliandria associada com a composição genética das ACZ maximiza a diversidade genética entre as colméias de determinada área.

Relações entre indivíduos de uma mesma colmeia são de grande importância, como, por exemplo, operárias que têm seus ovários inibidos em função das condições sociais, em algumas circunstâncias realizam postura de ovos não fertilizados, que dão origem a zangões. Quando a rainha estiver bem fertilizada por muitos zangões não aparentados, o parentesco entre uma operaria e o filho de outra operaria é menor que o parentesco entre uma operaria e os zangões filhos da rainha. Neste caso, as demais operárias podem impedir este tipo de operárias poedeiras (Ratnieks, 1990; Oldroyd et al. 1994). 
Koeniger et al. (2005b) observaram que os zangões têm maior preferência pelas ACZ que ficam mais próximas do apiário, argumentando a escolha destes locais por meio de duas hipóteses:

- Na primeira hipótese, os zangões jovens podem encontrar estas ACZ durante seus vôos de orientação, explorando passo a passo os arredores da colônia, estendendo seus vôos a áreas mais distantes. Segundo esta hipótese, os zangões utilizariam a primeira ACZ encontrada, a qual provavelmente é a ACZ mais próxima da colméia, assim, poucos machos ou nenhum visitariam mais que uma ACZ.

- Na segunda hipótese, cada macho explora toda a área de vôo que ele pode cobrir, encontrando assim todas as ACZ dos arredores, comparando e escolhendo, posteriormente, aquelas áreas mais favoráveis para os vôos de acasalamento futuros. Esta hipótese também prediz que uma proporção dos zangões pode visitar mais que uma $\mathrm{ACZ}$, já que 1 a $5 \%$ dos zangões marcados foram observados visitando duas ACZ.

A idéia que há uma fase de orientação, durante a qual os zangões exploram todas as ACZ e posteriormente cada zangão escolhe a ACZ mais atrativa (Koeniger et al., 2005b), torna a distância entre a colônia de origem e a ACZ como um dos principais fatores na decisão desta escolha. Em outras palavras, a escolha da ACZ mais próxima pode permitir ao macho prolongar sua presença na ACZ e incrementar sua chance de se acasalar. Os mesmos autores mencionam que a estratégia dos zangões na escolha da ACZ mais próxima induziria uma super-representação genética das colmeias próximas e incrementaria as diferenças genéticas entre as diferentes ACZ dentro de uma região.

Williams (1987) utilizou 3 armadilhas contendo cada uma $10 \mathrm{mg}$ de feromônio sintético 9-ODA, estas armadilhas foram instaladas a intervalos de $150 \mathrm{~m}$ uma da outra e ao longo de um canal a $600 \mathrm{~m}$ do apiário. A armadilha localizada a uma distância maior contra o vento capturou 793 zangões, mais do $80 \%$ do total dos indivíduos coletados nas três armadilhas.

Os zangões voam linearmente por meio de longas e/ou estreitas áreas. Os locais onde realizam vôos unidirecionais têm entre 50 e 100 m de comprimento, 
entre 60 e $150 \mathrm{~m}$ paralelos a bosques ou barreiras visuais de grande altura, ou em alguns casos, de estradas ou rodoviárias. Neste estudo realizado por Loper et al.( 1992), as rotas de vôos prevaleceram por até $1700 \mathrm{~m}$ e interligando três das ACZ encontradas. Estas ACZ podem ser vistas e encontradas ao longo das rotas de vôo, no entanto, nestes locais os zangões manobram, realizando vôos não unidirecionais, e em geral a altitude de vôo é maior. Os tamanhos das ACZ encontradas apresentaram um diâmetro entre 70 - $100 \mathrm{~m}$ e freqüentemente foram detectas onde a rota de vôo encontra uma barreira. Assim, a rota de vôo muda de direção ou se divide em duas ou mais rotas e nestes locais, geralmente ocorre uma ACZ. Foi visto por estes autores, que algumas ACZ podem estar conectadas.

Cristino (2003), considerou que todas as áreas descritas no seu trabalho foram áreas de manobras de reorientação em função da presença de marcos visuais ao longo dos trajetos de vôo. Os caminhos dos vôos de acasalamento até as ACZ podem ser considerados como uma rota de vôo ininterrupto. Desta forma os zangões saem da colônia para o vôo de acasalamento e depois de ganharem altura continuam em um vôo sem interrupções por rotas lineares intercaladas por áreas de reorientação (ACZ), concordando com os trabalhos realizados previamente por Loper et al., (1992).

Estas áreas de reorientação devem apresentar vantagens adaptativas para a reprodução, já que os machos não competem por recursos tróficos. A competição por acasalamento em locais de grandes agrupamentos de machos permite uma seleção daqueles melhores adaptados, além de permitir a ocorrência de um rápido acasalamento diminuindo os riscos inerentes ao meio ambiente (Krebs \& Davies, 1996). A poliandria também pode ter favorecido a evolução das ACZ (Koeniger \& Koeniger, 1991; 2000).

Quando a rainha não se encontra dentro da ACZ, os zangões se distribuem uniformemente dentro da ACZ. Aparentemente, os zangões não "predizem" os pontos com a maior probabilidade para encontrarem a rainha dentro da $\mathrm{ACZ}$ e não defendem territórios dentro desta área. Porém o comportamento dos zangões muda dramaticamente na presença e nas proximidades da rainha. A densidade dos zangões se eleva e os zangões parecem competir por melhores posições dentro do cometa para o acasalamento (Koeniger et al. 2005a). 


\subsection{PROCESSO DE AFRICANIZAÇÃO}

A abelha africana Apis mellifera scutellata e descendentes de seus cruzamentos com algumas abelhas européias, Apis mellifera mellifera, Apis mellifera carnica e Apis mellifera caucasica, existentes nos três continentes americanos, constituem as denominadas abelhas africanizadas (Gonçalves, 1992). O principal propósito que motivou a introdução desta subespécie de abelha africana foi o de desenvolver uma raça de abelha que deveria se adaptar melhor as condições Brasileiras, em comparação as abelhas européias que já colonizavam o Brasil e que apresentariam melhores porduções. Todas estas abelhas não são nativas do Brasil e foram introduzidas segundo Nogueira Neto (1962) em 1922 (introdução de abelhas Italianas Apis mellifera ligustica), no ano de 1839 (introdução de abelhas negras Alemãs Apis mellifera mellifera) e mais recentemente foram introduzidas outras abelhas como Apis mellifera carnica e Apis mellifera caucasica.

No ano 1956, o Professor Warwick Estevam Kerr, após a devida autorização das autoridades pertinentes, enviou 133 rainhas africanas (Apis mellifera scutellata) para iniciar um programa de melhoramento visando obter híbridos que tivessem a mansidão das abelhas européias e a produtividade das africanas. Das 133 rainhas enviadas, somente 47 delas sobreviveram, originando em 1957 um total de 35 colônias puras de abelhas africanas, que se constituíram no estoque genético africano inicial, introduzidas no Horto de Camaquan, no Município de Rio Claro - SP. Devido a um acidente durante o manejo destas abelhas, onde inadvertidamente foram retiradas as telas excluidoras destas colmeias, 26 delas enxamearam para a natureza e assim deu-se inicio ao processo de africanização das abelhas européias no Brasil (Gonçalves, 1974).

Estas abelhas, após se cruzarem livremente e por serem todas elas subespécies de Apis mellifera, deveriam dar origem a descendentes que, supostamente, dividiriam igualmente o mesmo nicho ecológico e apresentariam uma ampla variabilidade de características intermediárias entre as distintas subespécies, porém sem dominância marcante de uma única espécie. No entanto, 
surpreendentemente, nos descendentes polihíbridos houve uma significativa dominância dos genes africanos na maioria de suas características morfológicas, fisiológicas e comportamentais. Essa dominância trouxe, como conseqüência, um fenômeno internacionalmente conhecido como Africanização das abelhas, o qual causou sérios impactos biológicos, econômicos e sociais (Gonçalves, 2001).

Para entender melhor a interação entre as abelhas africanizadas e as abelhas européias nas Américas é muito importante conhecer parte da ecologia de seus ancestrais. Estes ancestrais na Europa e África faziam parte de ecossistemas muito diferentes. A diversidade de ecossistemas na África é muito alta, ocorrendo igualmente grande diversidade nas abelhas africanas, as quais estavam bem adaptadas. $\mathrm{O}$ ancestral africano da abelha africanizada, a subespécie Apis mellifera scutellata, habita em uma região de clima árido ou semi-árido com baixos índices pluviométricos que interferem diretamente no crescimento de plantas, floradas, gerando fluxos de néctar e pólen escassos. Por outro lado, a Europa é um continente com ciclos sazonais preditos, onde as abelhas européias estão adaptadas a este tipo de clima, podendo perceber, por meio do foto-período, quando cada estação vai se apresentar e em conseqüência disso quando terá nova florada, maior fluxo de néctar, nevadas, entre outros fatores (Rinderer \& Hellmich, 1991).

A dominância dos genes africanos trouxe como resultado a manifestação de algumas características nas abelhas africanizadas como: Redução do tamanho das células do favo de operárias; menor tamanho das operárias; diminuição do período de desenvolvimento das operárias, rainhas e zangões; maior atividade forrageira; maior número de espermatozóides estocado na espermateca das rainhas; maior atividade de postura; menor peso das rainhas ao emergir; maior capacidade de adaptação ambiental dos enxames; além dos zangões, filhos de rainhas africanizadas, serem $29 \%$ mais eficientes na cópula do que os zangões filhos de rainhas européias (Gonçalves, 2002).

Segundo Rinderer \& Hellmich (1991), a biologia do processo de Africanização pode ser dividida em duas categorias principais. A primeira delas envolve a dispersão das abelhas africanizadas dentro de uma área e a segunda envolve a redução da contribuição genética das abelhas européias na população em 
geral. As abelhas africanizadas se dispersaram para novas áreas, principalmente pelo movimento de enxames de evasão, evidências no Kenya sugerem que abelhas africanas podem viajar durante cada evasão por distâncias entre 60 e 80 km.

Linhagens paternas européias, estando em zonas de invasão, poderiam se perder quando produzissem novas rainhas. Durante este processo, a colmeia produziria uma nova rainha virgem, que se acasalaria com uma mistura de zangões africanizados e europeus, como resultado estas colônias possuiria operárias com linhas paternas européias e africanizadas. Durante o processo de troca de rainha, estas colônias produziram rainhas das duas linhagens, porém, a linhagem paterna africanizada possui uma vantagem adaptativa. Assim, rainhas provenientes de linhas paternas africanizadas desenvolvem-se mais rapidamente e emergem antes das rainhas provenientes das linhagens paternas européias (Schneider et al. 2004).

Um dos aspectos mais notáveis da abelha africana é sua habilidade para deslocar as subespécies de abelhas européia no Novo Mundo. Inicialmente, assumiuse que abelhas européias e africanas poderiam intercruzar-se, dando origem à abelha africanizada típica da América Latina. Porém, embora ocorra uma hibridação substancial, quando abelhas africanas invadem áreas com populações européias, as características iniciais européias tendem a se perder ao longo do tempo (Clarke et al., 2001; Clarke et al., 2002; Diniz \& Malaspina, 1995; Hall, 1999; Loper, 2002; Nielsen et al., 2000; Quezada-Euán et al., 1996; Quezada-Euán \& Paxton, 1999; Segura, 2000; Suazo et al., 1998 e Taylor, 1999). De fato, devido ao seu grande alcance no Novo Mundo, as populações de abelhas invasoras têm se mantido essencialmente africanas na sua biologia de nidificação (Mcnally \& Schneider, 1992), comportamento de enxameação e evasão, forrageio e seleção da dieta, e características do mtDNA (Schneider et al., 2004).

O conceito de enxame híbrido foi seriamente questionado quando polimorfismos de mtDNA revelaram que mais de 97\% das colônias naturais do Brasil, Venezuela, Honduras e México, possuíam haplótipos de mtDNA africanos, enquanto os mitótipos europeus estavam virtualmente ausentes. Como o mtDNA das abelhas é herdado via materna sem recombinação, isto indicou que as colônias naturais africanizadas são descendentes de linhas maternas africanas, em sua maioria 
Apis mellifera scutellata (Hall \& Muralidharan, 1989; Hall \& Smith, 1991 e Smith et al., 1989).

Populações de abelhas africanizadas do Brasil têm estado em contato com abelhas européias desde 1956 e isto se constitui no maior período de tempo de convivência destas subespécies nas Américas. Porém, 35 anos após a introdução das abelhas africanas ao Brasil, $100 \%$ de 126 colméias naturais apresentaram características de mtDNA de abelhas Apis mellifera scutellata (Sheppard et al., 1991).

A dispersão das abelhas africanizadas pelas Américas foi bem documentada, podendo chegar a se dispersar entre 80 e $500 \mathrm{~km}$ por ano (Taylor, 1985; Rinderer, 1986). Colônias de abelhas africanizadas foram detectadas no sul do Texas em 1990 (Sugden \& Williams, 1990), no sul do Arizona e na Califórnia no ano de 1995. (Vissscher et al., 1997). Segundo Kerr et al. (1982), a dispersão destas abelhas no sentido sul do continente americano foi completada no ano 1976, quando estas populações encontraram limites climáticos (temperatura) no sul da Argentina que impediram que continuassem se dispersando (ver figura 3). Analisando populações de abelhas do Sul do Brasil e do Uruguai, Diniz et al. (2003) confirmaram a existência de uma zona de transição de populações de abelhas geneticamente distintas na parte sul do Brasil e Uruguai, e que este limite para abelhas africanizadas pode ser localizado entre o paralelo $30^{\circ}$ e $35^{\circ}$ Sul. Os autores finalmente concluíram, por informações moleculares, que o processo de africanização de populações de abelhas em Uruguai foi completado.

Devido ao impacto biológico que estas abelhas poderiam causar, os Estados Unidos instalaram em 1987, uma "barreira Biológica" localizada no Istmo de Tehuantepec no México, com o intuito de bloquear a passagem das abelhas africanizadas aos Estados Unidos. Apesar do grande esforço e do alto investimento do programa, não houve o sucesso esperado, atingindo toda a área mexicana em menos de quatro anos e parte sul dos Estados Unidos (Gonçalves, 1992). 


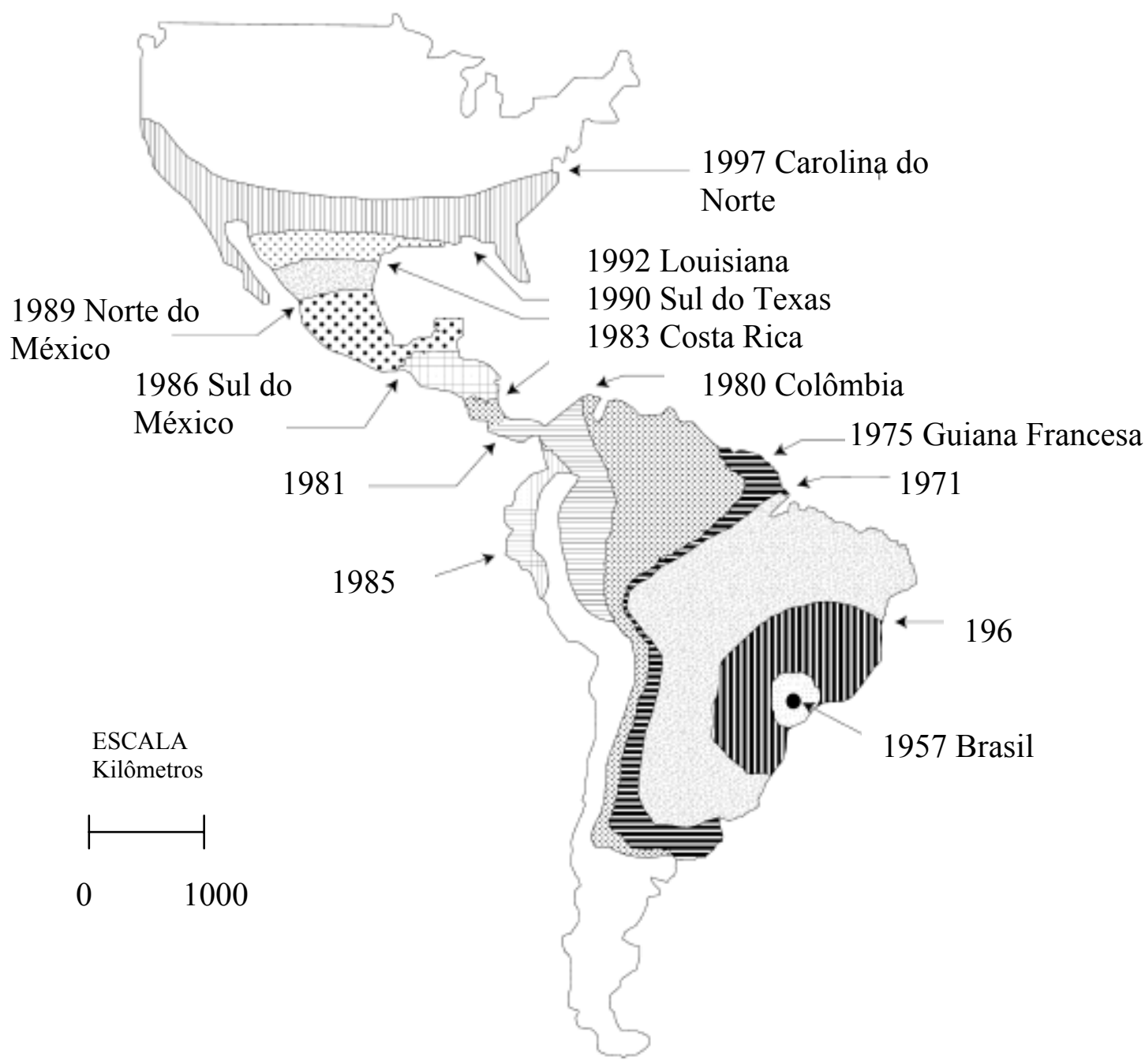

Figura 3 - Dinâmica de dispersão das abelhas africanizadas nas Américas (modificado de Mistro et al., 2005).

Quando as abelhas africanizadas colonizam áreas com populações de abelhas européias residentes, as rainhas se acasalam principalmente com zangões africanizados, o qual resulta num deslocamento rápido de linhas paternas européias em colônias naturais e manejadas. Um grande componente deste fenômeno é a superioridade numérica dos zangões africanizados, os quais provêm de: (a) Uma produção proporcionalmente maior de zangões por colônias africanizadas que por colônias européias (Otis et al., 2002 e Rinderer et al., 1987); (b) os zangões africanizados entram e são mantidos em colônias européias, as quais suprimem a produção de zangões europeus (Rinderer et al., 1985) e (c) altas taxas de perdas de rainhas em colônias africanizadas (Mcnally \& Schneider, 1992 e Otis, 1991), as 
quais resultam em colônias órfãs que criam grandes quantidades de zangões filhos de operárias (DeGrandi-Hoffman \& Schneider, 2002 e Zillikens et al., 1998). Outros fatores também podem contribuir para uma vantagem reprodutiva: Padrões sazonais de produção de zangões, que favorecem o acasalamento das rainhas com machos africanizados, durante certos períodos do ano (Echazarreta \& Paxton, 1997; Quezada-Euän \& May-Itza, 2001); características comportamentais de vôo que promovem os acasalamentos entre rainhas européias e zangões africanizados, mas diminui as chances de acasalamentos recíprocos (Taylor, 1999); e o possível uso de espermatozóides africanizados em maiores quantidades por rainhas acasaladas com zangões europeus e africanizados (DeGrandi-Hoffman et al. 2003). Em combinação estes fatores podem ter favorecido a uma maior introgressão de alelos paternais africanizados em colônias européias e uma pequena introgressão de marcadores paternais europeus em colônias africanizadas (Schneider et al., 2004).

Após de 11 anos de estudos da estrutura genética de populações localizadas no sul dos USA, Pinto et al., (2005), usando marcadores moleculares (microssatélites) revelaram que o processo de africanização envolveu fluxo de genes maternos e paternos entre populações européias e africanizadas; e que populações panmíticas de abelhas européias foram substituídas por populações panmíticas de abelhas africanizadas e européias após 5 anos da africanização. $O$ pool gênico após a africanização (entre 1998 e 2001), estva composto de uma disposição diversa de classes recombinantes, com uma contribuição genética européia substancial (25$37 \%$ ), conseqüentemente, abelhas silvestres do sul do Texas são vistas como um enxame híbrido. 


\section{MATERIAL E MÉTODOS}

\subsection{ANÁLISE DA ATIVIDADE DE VÔO}

O estudo da atividade de vôo de rainhas e zangões africanizados e europeus (Apis mellifera africanizada e Apis mellifera carnica) foi realizado no Apiário Experimental do Departamento de Genética da Faculdade de Medicina de Ribeirão Preto - Universidade de São Paulo.

As rainhas africanizadas foram obtidas de matrizes mantidas no apiário do próprio Depto de Genética, provenientes de enxames coletados na natureza e as rainhas européias Apis mellifera carnica, foram obtidas de rainhas provenientes de apiários comerciais europeus. A introdução das rainhas nas colmeias de observação foi realizada em duplicata, totalizando dez observações em cada subespécie analisada.

Para o registro do comportamento de vôo das rainhas, foram montados dois núcleos com 4 favos cada e nos quais foi instalado um vestíbulo no alvado de cada núcleo.

Como se pode observar na figura 4, o vestíbulo foi fixado diretamente na entrada do núcleo, criando desta forma um corredor pelo qual as abelhas tiveram obrigatoriamente que passar antes de sairem para o vôo. Este vestíbulo foi coberto por uma placa de vidro que permitiu observar e registrar a saída e a entrada da rainha durante os vôos de orientação e acasalamento (modificado de Tozetto, 1997). 


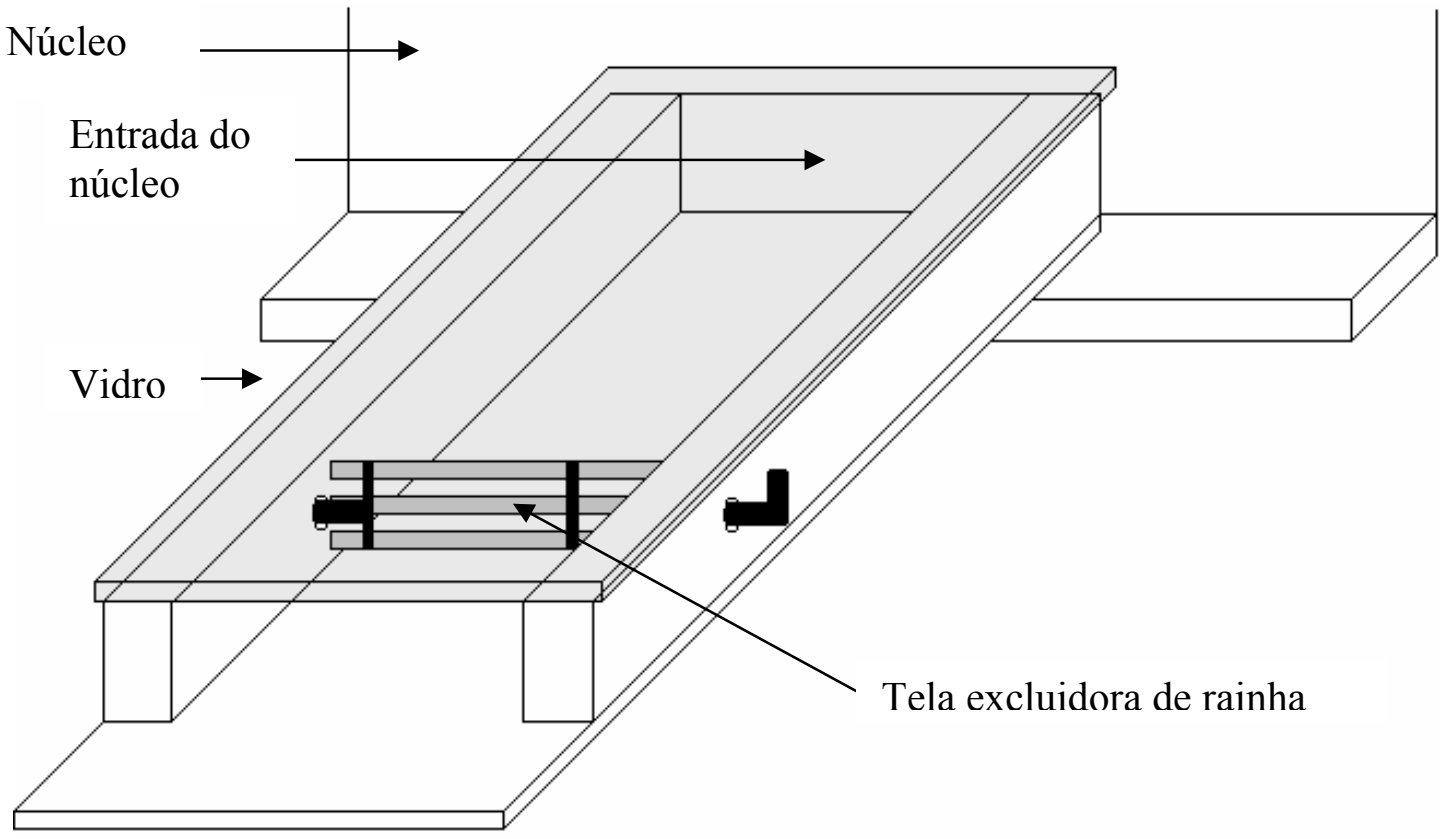

Figura 4 - Desenho esquemático do vestíbulo instalado na entrada dos núcleos e mini-recrias (modificado de Tozetto, 1997).

As rainhas experimentais foram produzidas mediante o método Doolitle (1899), no qual as células reais, após 10 dias da transferência, foram retiradas das mini-recrias e mantidas em estufa com temperatura e umidade controladas, para a emergência. Posteriormente estas rainhas com até um dia de vida foram respectivamente marcadas e introduzidas nos núcleos de observação. A introdução das rainhas foi realizada por médio de uma tela protetora, as quais foram retiradas, aproximadamente, 48 horas após serem introduzidas. Este método garante uma aceitação de $100 \%$ das rainhas introduzidas.

Após, aproximadamente, o terceiro dia de vida da rainha e estando um dia livre na colônia, deu-se o inicio das observações do comportamento de vôo destas. Adicionalmente, foi instalado no vestíbulo uma tela excluidora de rainha, que permitiu o controle durante as observações, já que durante o período da tarde geralmente ocorrem os vôos de orientação das operárias, fato que envolve um grande fluxo de abelhas saindo e ingressando no núcleo, durante determinados períodos do dia. Quando a rainha era avistada no vestíbulo, a tela excluidora era desativada para permitir a saída, uma vez com a rainha fora da colméia a tela excluidora era novamente ativada. Isto garantiu a observação da rainha no momento que retornava 
ao núcleo e ao mesmo tempo permitiu observar se a rainha apresentava ou não a marca de acasalamento.

As observações do comportamento de vôo das rainhas foram realizadas após do terceiro dia da introdução, durante os dias necessários até que a rainha retornasse com a marca de acasalamento ou por um período máximo dez dias. Com o retorno da rainha ao núcleo com a marca de acasalamento, não foram realizadas mais observações, porém, a tela excluidora continuou impedindo a saída da rainha. Durante as observações do comportamento das primeiras 5 rainhas virgens de cada subespécie, analisou-se o intervalo de tempo entre as 13:00 e 17:00 h do dia. Posteriormente, o inicio das observações foi realizado a partir das 14:00 horas, registrando-se, assim, os respectivos dados para cada vôo das rainhas.

Em seguida, os mesmos núcleos foram orfanados, isto é, preparou-os para receberem uma nova rainha virgem e assim dar continuidade às observações. As rainhas, agora já fecundadas e que se encontravam nos núcleos, foram presas em gaiolas de transporte. Após a confirmação do inicio da postura, como a verificação da presença das crias jovens (ovos e larvas) nos favos de cada núcleo, estas rainhas foram dissecadas com o objetivo de observar o estado da espermateca.

Para o registro do comportamento de vôo dos zangões, foram instaladas duas mini-recrias formadas por dois núcleos superpostos com 5 favos cada uma, totalizando, assim, 10 favos por mini-recria. Uma destas mini-recrias possuia uma rainha africanizada filha de uma colmeia já existente no apiário do Depto de Genética da USP e acasalada naturalmente; a outra possuía uma rainha cárnica filha de outra rainha cárnica pura originária de apiários europeus e mantida no apiário experimental do Depto de Genética da USP e também acasalada naturalmente. As rainhas de cada mini-recria foram produzidas mediante o método Doolitle (1899), após as rainhas emergirem, foram respectivamente marcadas e introduzidas nas minirecrias. Com a confirmação do início da postura destas rainhas, estas foram levadas para uma área de cerrado natural com o intuito de permitir-lhes um desenvolvimento adequado.

Após a introdução das respectivas rainhas nas mini-recrias, estas permaneceram, aproximadamente, entre 4 e 5 meses no apiário localizado na Estação 
Ecológica de Jataí, Luiz Antônio - SP. Após este período, as mini-recrias apresentaram boas condições e com o início do fluxo de alimento, as rainhas iniciaram a produção machos. Após a confirmação da presença de zangões nas minirecrias, estas foram levadas novamente ao apiário localizado no campus da USP de Ribeirão Preto para dar início as observações do comportamento de vôo. Adicionalmente estas mini-recrias também receberam vestíbulos instalados no alvado, como já descrito acima, facilitando as observações dos zangões durante os períodos da tarde.

Um dia após este transporte, foram marcados, aleatoriamente, zangões maduros que estavam localizados, principalmente, nos favos com alimento. Tais machos, que já estavam realizando vôos de acasalamento, receberam marcas numeradas e de cores diferentes (tipo Opalith), totalizando 126 machos carnicos e 146 machos africanizados. Após esta etapa iniciou-se as observações do comportamento de vôo dos zangões.

As observações dos horários de vôo dos zangões foram efetuadas durante o período da tarde, entre 14:00 e 17:00 h, horário no qual são realizados os vôos de acasalamento. Devido ao grande número de zangões e operárias entrando e saindo em cada mini-recria, foi impossível registrar o horário e o tempo de vôo de cada indivíduo. Assim, nas observações do comportamento de vôo dos zangões foi registrado o número de zangões africanizados e/ou carnicos que saíram da colmeia em intervalos de 5 minutos, estas observações do comportamento foram realizadas durante 4 dias consecutivos.

\subsection{ANÁLISE DAS ÁREAS DE CONGREGAÇÃO DE ZANGÕES (ACZ)}

Após observar o comportamento de zangões e rainhas, tanto de abelhas africanizadas como de européias, deu-se inicio às observações nas ACZ.

Foram determinados pontos dentro da área do campus da USP de Ribeirão Preto, como possíveis ACZ. Para a determinação de tais pontos foram consideradas as áreas abertas, áreas localizadas a diferentes distâncias do apiário experimental e 
áreas com diferentes altitudes. Estes pontos foram localizados na imagem de satélite que ofereceu o programa Google Earth Home versão 4-Beta.

Nestas possíveis ACZ foi levantado um balão de borracha preenchido com gás hélio, preso a um fio fino de nylon, pelo qual controlou-se a altitude e movimentação deste pelas ACZ. Junto ao balão, pendurada a uma distância de 1,5 metros, foi presa uma gaiola plástica, usada para transporte e introdução de rainhas, contendo uma rainha fecundada, a qual exerce uma grande atração aos zangões.

Para registrar a velocidade do ar $(\mathrm{m} / \mathrm{s})$ foi utilizado um Anemômetro Digital Portátil Modelo AD-250 (Instrutherm), registrando entre 0,4 e 30,0 m/s, com resolução de $0,1 \mathrm{~m} / \mathrm{s}$ e uma erro de $\pm 3 \%$. Adicionalmente, foi usado uma vara telescópica de 7,5 metros de comprimento. Por médio desta vara o anemômetro foi levantado e exposto ao vento a 7,5 m do chão durante cada intervalo de observação. Após cada observação era feita a leitura do anemômetro.

A intensidade luminosa foi registrada por médio de um Luxímetro Digital MLM-1010 (Minipa), resolução entre 1 e 10.000 lux e uma erro menor de $\pm 5 \%$.

Como ferramenta para determinar o número de machos nas ACZ, foi usada uma câmera digital Sony CyberShot DSC-H1 de 5.1 Megapixels, e zoom ótico de $12 X$.

Assim, o balão com uma rainha fecundada foi levantado em cada um dos pontos e dos quais foram coletados os respectivos dados: Número aproximado de zangões, velocidade do ar e luminosidade. As observações foram realizadas durante o período da tarde, entre 14:00 e 17:00 h, e por intervalos alternados de tempo de 10 minutos, obtendo-se, durante uma tarde, aproximadamente 10 observações. Durante o intervalo, o balão foi descido e somente no próximo intervalo de tempo o mesmo foi novamente levantando, permitindo que após as observações os zangões se dispersassem novamente e não ficassem atraídos pelo feromônio que a rainha pressa estava liberando. Tais observações foram realizadas em dias que não apresentaram chuvas no período da tarde, fator determinante na realização das observações, no entanto, foram realizadas observações durante alguns dias nublados.

Para uma maior exatidão, os dados meteorológicos de temperatura e umidade relativa do ar, durante os experimentos, foram coletados junto ao Centro Avançado 
de Pesquisa Tecnológica do Agronegócio de Cana do "Instituto Agronômico", localizado a 4,317 Km do campus da USP.

\subsection{COLETA DE ZANGÕES NAS ACZ}

Foram marcados aproximadamente 600 zangões de diferentes colônias, com o objetivo de associá-los as ACZ encontradas. Em duas ocasiões foram marcados, com tintas automotivas de diferentes cores, zangões considerados maduros e que conseqüentemente já estavam realizando vôos de acasalamento.

Para a coleta e captura dos zangões dentro das ACZ foi utilizada uma armadilha aérea, semelhante a mesma descrita por Taylor (1984), porém, com algumas modificações propostas por Cristino (2003), como pode ser observado na figura 5. Esta armadilha também foi levantada por médio do balão de Hélio (figura $6)$.

As coletas dos zangões foram realizadas durante os horários da tarde, que apresentam uma maior concentração de zangões atraídos pela isca.

Os zangões, coletados nas diferentes ACZ, foram observados para verificar a origem, zangões já marcados, sendo posteriormente foram soltos na ACZ.

Todos os dados coletados foram analisados usando o programa estatístico "SigmaStat 3.1", por meio de diferentes análises estatísticas, segundo cada caso. Quando os dados apresentaram uma distribuição normal foram analisados pelo teste “t”, ou mediante o teste "Mann-Whitney Rank Sum”, quando os dados não apresentaram uma distribuição normal. 


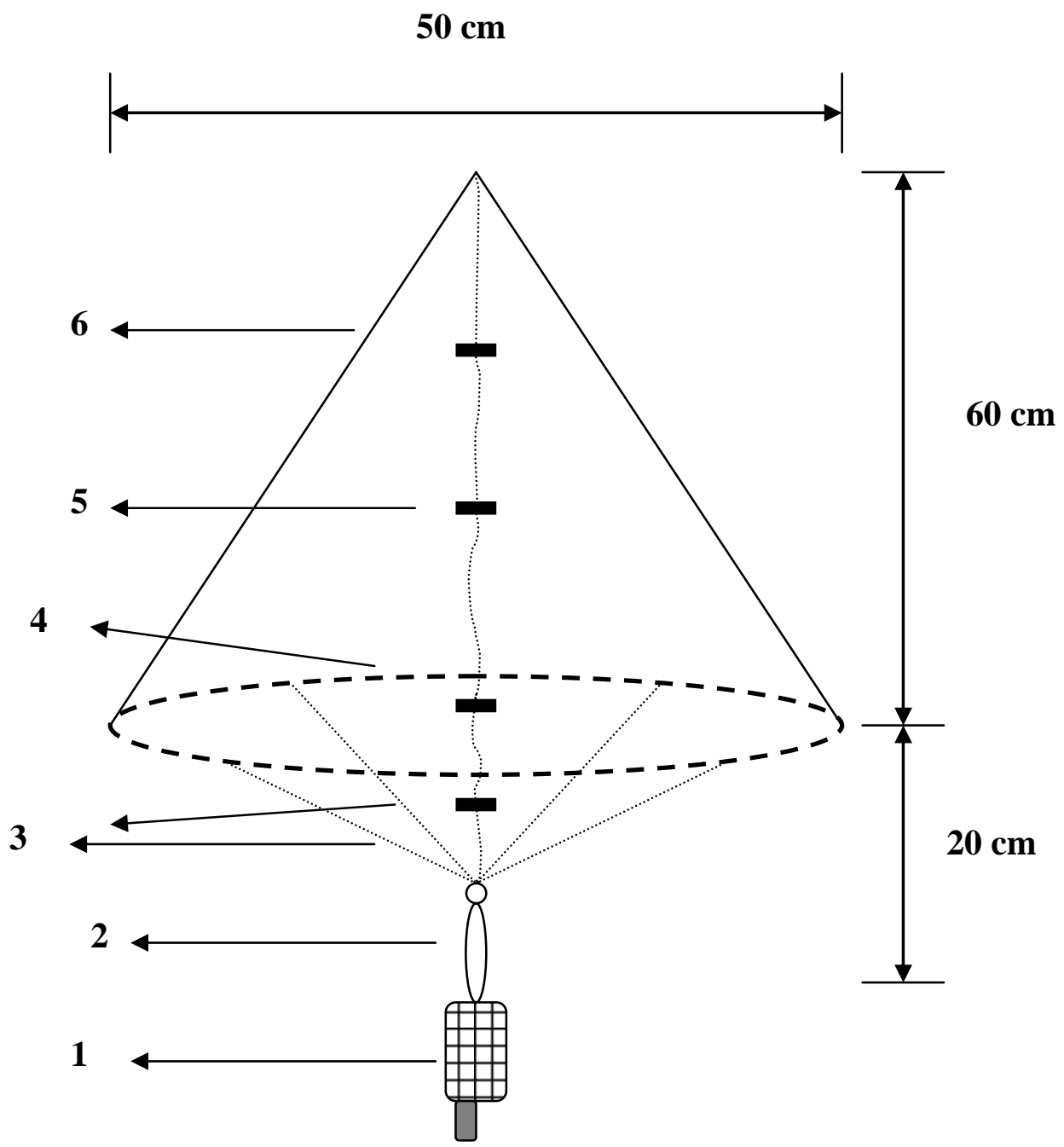

Figura 5 - Armadilha aérea utilizada para capturar os zangões nas ACZ: 1) gaiola contendo uma rainha fecundada e algumas operárias; 2) fio de nylon grosso $(0,9 \mathrm{~mm}) ; 3)$ fio de nylon fino (0,2 mm); 4) arame (1,5 mm); 5) tubo de borracha; 6) rede de filó branca.

A metodologia usada para as ACZ e para as coletas de zangões durante estas observações pode ser facilmente observada na figura 6 . Onde, por médio de um balão de borracha, foi levantada uma rainha fecundada ou uma armadilha junto com a rainha. 


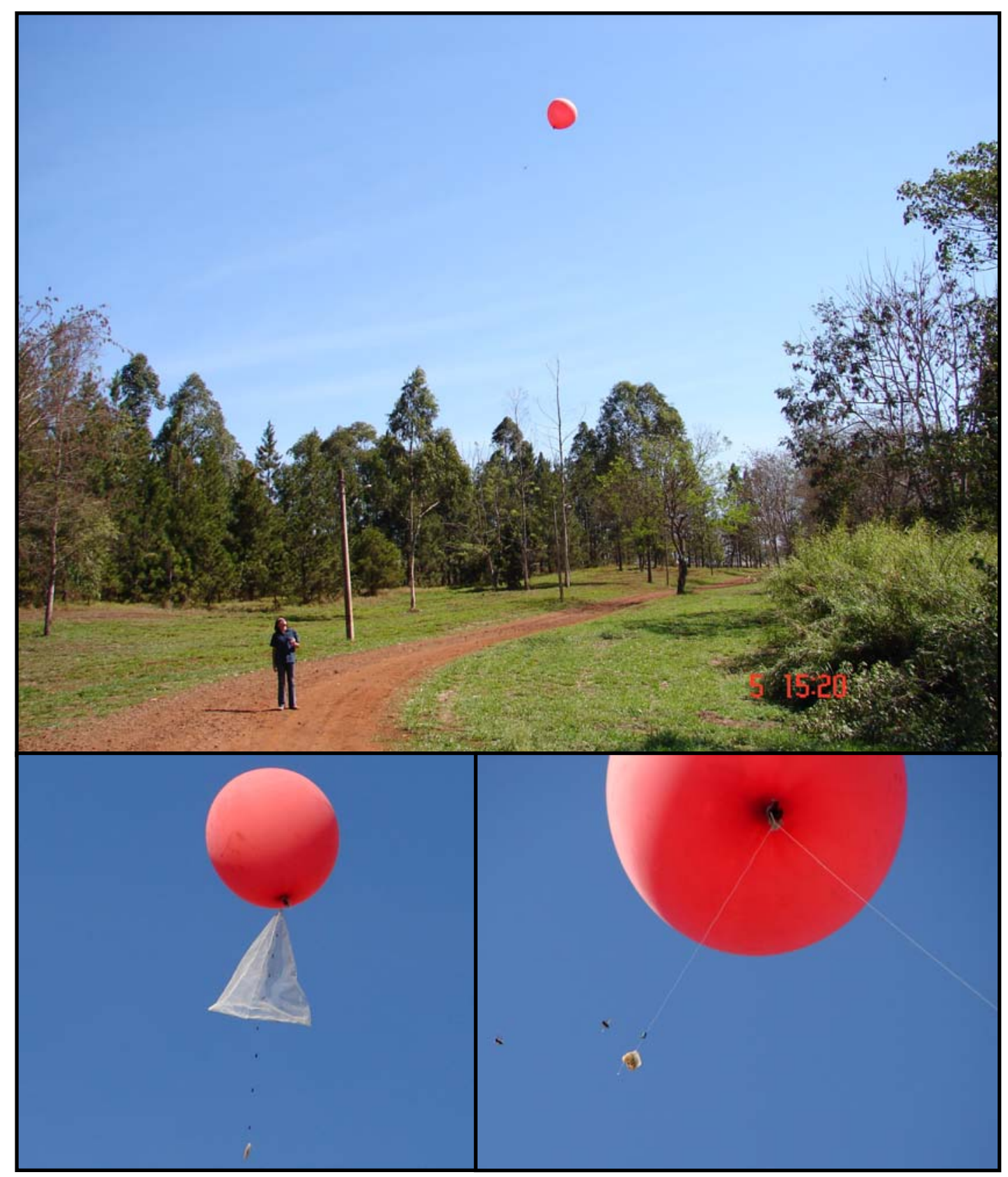

Figura 6 - Metodologia usada nas observações e nas coletas de zangões nas ACZ. 


\section{RESULTADOS}

\subsection{COMPORTAMENTO DE VÔO DAS RAINHAS AFRICANIZADAS E RAINHAS CARNICAS}

As rainhas foram introduzidas nos núcleos a cada 12 ou 13 dias, aproximadamente, não sendo necessário reforçar estes núcleos com favos de outras colônias. Os resultados deste experimento revelaram, mediante o método de introdução usado, que obteve-se $100 \%$ de aceitação das rainhas introduzidas, comprovando que a metodologia aplicada durante este procedimento foi muito eficiente.

Durante todo o experimento de observação da atividade de vôo de rainhas, observou-se que somente duas rainhas, correspondentes à linhagem africanizada, não retornaram ao núcleo após terem saído para efetuar seu respectivo vôo. Tal informação revela-nos o risco ao qual a rainha está exposta durante o vôo de acasalamento, deixando a colmeia sem uma fêmea reprodutiva por um período de tempo desconhecido. Também, verificou-se que todas as rainhas acasaladas retornaram ao núcleo com a marca de acasalamento e que depois de alguns dias iniciaram o processo de postura. Em geral, estas rainhas retornaram, permanecendo na entrada no núcleo e após alguns minutos entraram. Constatou-se uma dificuldade das rainhas em reconhecer os respectivos núcleos.

As rainhas carnicas realizaram seus vôos de acasalamento após as 14:00 h, até o horário máximo observado de 16:10 horas. As rainhas africanizadas realizaram seus vôos de acasalamento após as 14:36 h, até o horário máximo de 15:56 horas. Alguns resultados referentes ao comportamento de vôo de rainhas carnicas e 
africanizadas podem ser vistos na Tabela 1. Como foi comentado anteriormente, durante esta fase experimental, duas rainhas africanizadas não retornaram de seu vôo.

Tabela 1 - Resultados obtidos durante o comportamento de vôo das rainhas carnicas e européias em função dos determinados comportamentos.

\begin{tabular}{|c|c|c|c|c|c|c|c|c|c|c|}
\hline & \multicolumn{2}{|c|}{$\begin{array}{c}\text { Idade no } 1^{\circ} \text { vôo } \\
\text { (dias) }\end{array}$} & \multicolumn{2}{|c|}{$\begin{array}{c}\text { Idade no vôo de } \\
\text { acasalamento } \\
\text { (dias) }\end{array}$} & \multicolumn{2}{|c|}{$\begin{array}{c}\text { Números de } \\
\text { vôos }\end{array}$} & \multicolumn{2}{|c|}{$\begin{array}{c}\text { Duração do vôo } \\
\text { de acasalamento } \\
\text { (minutos) }\end{array}$} & \multicolumn{2}{|c|}{$\begin{array}{l}\text { Temperatura } \\
\text { ambiente }\left({ }^{\circ} \mathrm{C}\right)\end{array}$} \\
\hline & CAR & $A F R I$ & CAR & $A F R I$ & $C A R$ & $A F R I$ & $C A R$ & $A F R I$ & $C A R$ & $A F R I$ \\
\hline Média & 7,1 & 6,1 & 8,5 & 7,12 & 2,5 & 2,87 & 20,3 & 18,62 & 28,76 & 28,51 \\
\hline Desvio & 1,91 & 1,28 & 1,58 & 1,80 & 0,97 & 1,45 & 2,45 & 4,17 & 1,91 & 2,07 \\
\hline $\mathbf{N}$ & 10 & 10 & 10 & 8 & 10 & 8 & 10 & 8 & 10 & 8 \\
\hline
\end{tabular}

Os dados referentes ao vôo das rainhas africanizadas e carnicas neste experimento foram analisados mediante o teste "t-student" ou pelo teste "MannWhitney Rank Sum”, quando os dados não apresentavam uma distribuição normal. Revelando-nos que não existem diferenças estatísticas significativas $(\alpha=0,05 \%)$ entre as duas subespécies ao compararmos:

- $\quad$ A idade da rainha no primeiro vôo $(\mathrm{T}=123: \mathrm{P}=0,185)$.

- A idade da rainha no vôo do acasalamento $(t=1,721 ; \mathrm{P}=0,104)$.

- $\mathrm{O}$ número de vôos de cada rainha $(\mathrm{T}=79,5 ; \mathrm{P}=0,789)$.

- A duração do vôo de acasalamento ( $t=1,065 ; \mathrm{P}=0,303)$.

- Temperatura ambiente no dia do vôo de acasalamento $(t=0,263 ; \mathrm{P}=0,796)$.

O comportamento das rainhas africanizadas e carnicas podem ser facilmente observados na figura 7, onde há uma comparação dos diferentes parâmetros observados em cada subespécie. 


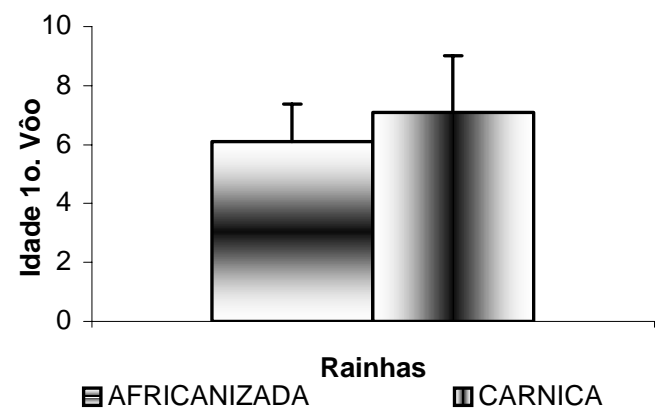

A) Idade média das rainhas ao primeiro vôo.

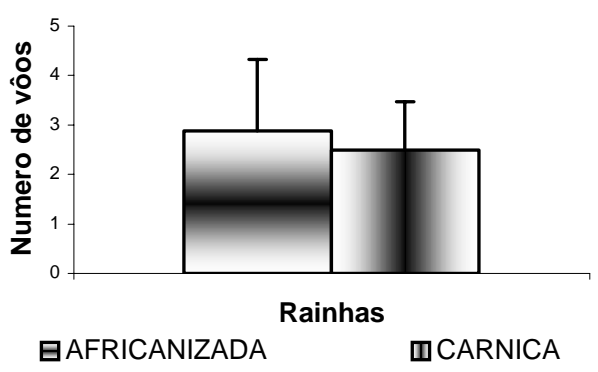

C) Número médio de vôos das rainhas.

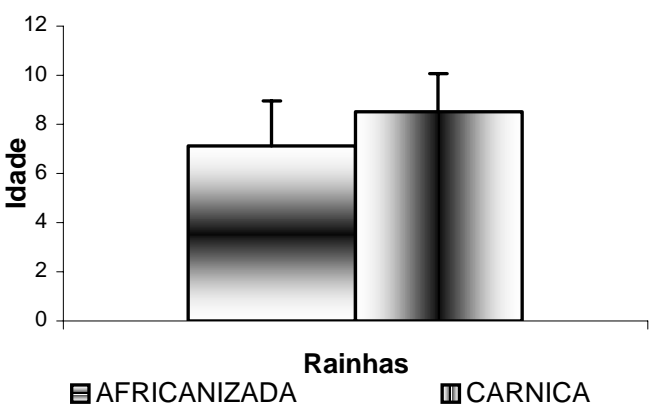

B) Idade média das rainhas durante o vôo de acasalamento.

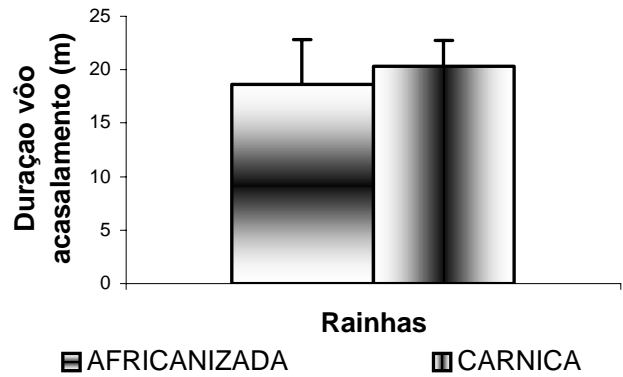

D) Tempo médio de duração do vôo de acasalamento (minutos).

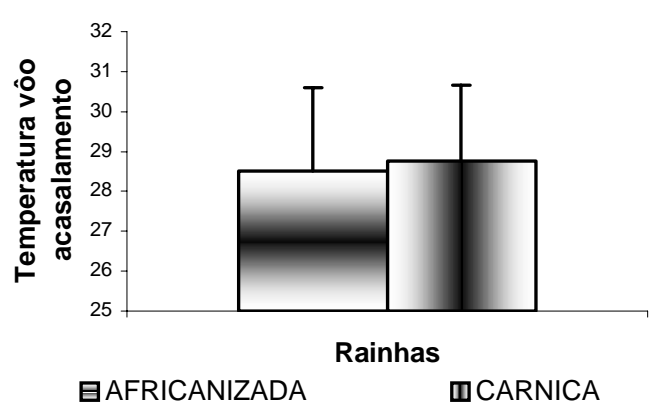

E) Temperatura ambiente média durante os vôos de acasalamento.

Figura 7 - Principais parâmetros do comportamento de vôo de rainhas africanizadas e carnicas de Apis mellifera. 
Verificamos que existe uma tendência por parte das rainhas africanizadas em realizarem os vôos de orientação e de acasalamento mais jovens, fato também observado durante o vôo de acasalamento, onde rainhas africanizadas efetuaram estes vôos em um intervalo de tempo menor ao observado nas rainhas européias. No entanto, rainhas européias realizaram, em média, menor número de vôos em comparação as rainhas africanizadas. Como este experimento foi realizado em duplicata, uma rainha para cada subespécie, e durante o mesmo intervalo de tempo, observamos que a temperatura não foi um fator ambiental que estivesse determinando o comportamento de vôo destas rainhas.

O horário no qual rainhas africanizadas e rainhas carnicas realizam seus vôos de acasalamento revelaram-nos que ambas rainhas realizam seus vôos, preferencialmente, durante o intervalo da tarde, entre 14:00 e 15:00 horas (figura 8), não sendo encontradas diferenças significativas no horário do dia no qual os vôos de acasalamento foram realizados $(t=0,0 ; \mathrm{P}=1,0)$.

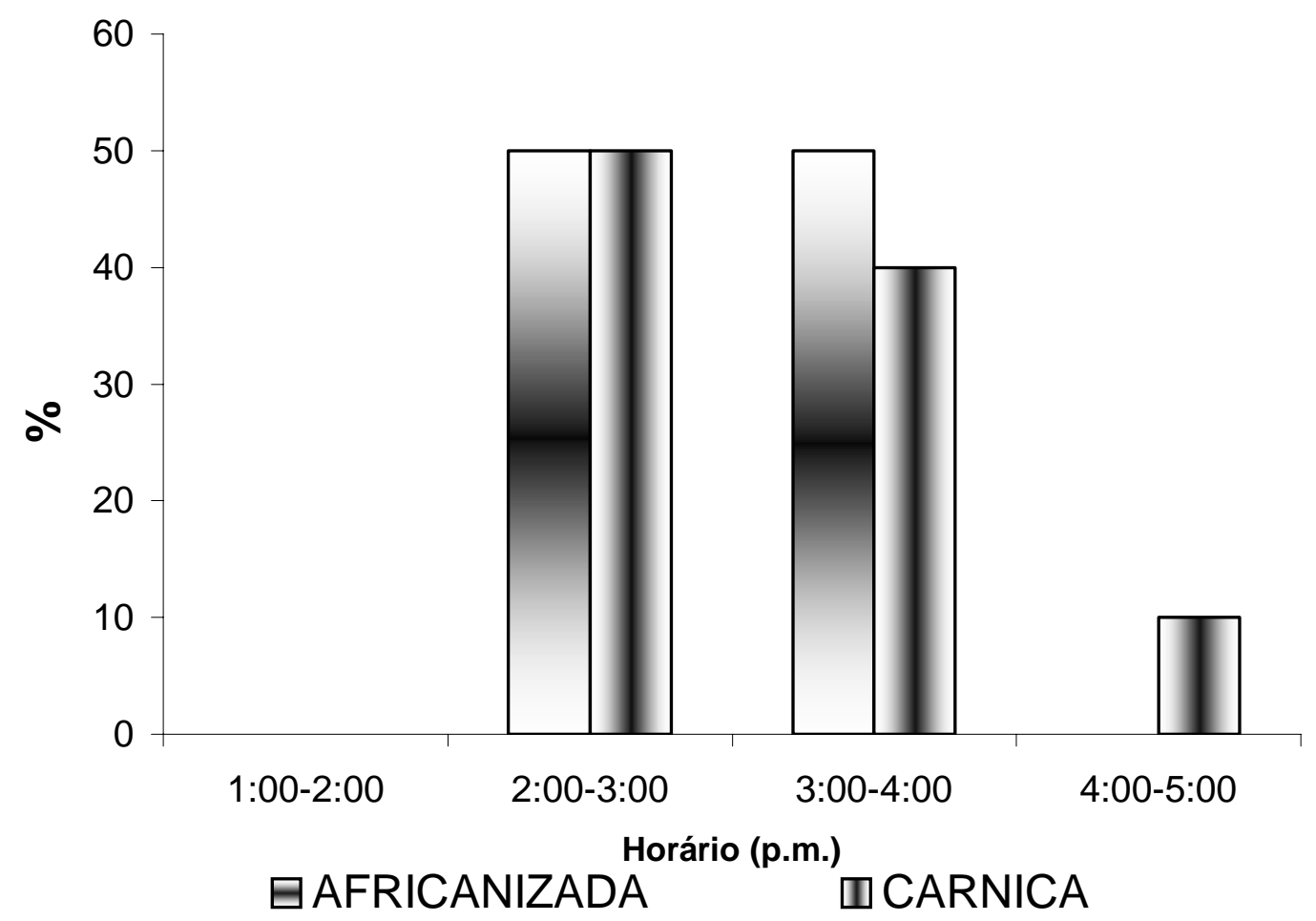

Figura 8 - Horário da tarde no qual as rainhas africanizadas e carnicas realizaram o vôo de acasalamento. 
Das 18 rainhas que retornaram aos núcleos com a marca de acasalamento, $100 \%$ delas realizaram postura. Todas as rainhas dissecadas apresentaram uma espermateca típica de rainhas comumente acasaladas, ou seja, foi possível constatar que a espermateca se encontrava cheia de esperma.

\subsection{COMPORTAMENTO DE VÔO DE ZANGÕES AFRICANIZADOS E ZANGÕES CARNICOS}

Foi registrado durante esta fase, o número de zangões saindo e retornando à mini-recria em intervalos de 5 minutos. Durante estas observações encontramos que o inicio da atividade de vôo nunca antecedeu o horário das 14:15 e 14:30 horas para zangões carnicos e africanizados respectivamente, apresentando um pico de atividade no horário da tarde entre as 15:00 e 15:30h, como apresentado na figura 9. Segundo as análises estatísticas não existem diferenças significativas entre os zangões africanizados e carnicos quanto ao período do dia no qual realizaram os vôos $(\mathrm{t}=$ $3,11 \mathrm{E}-015 ; \mathrm{P}=1,000)$.

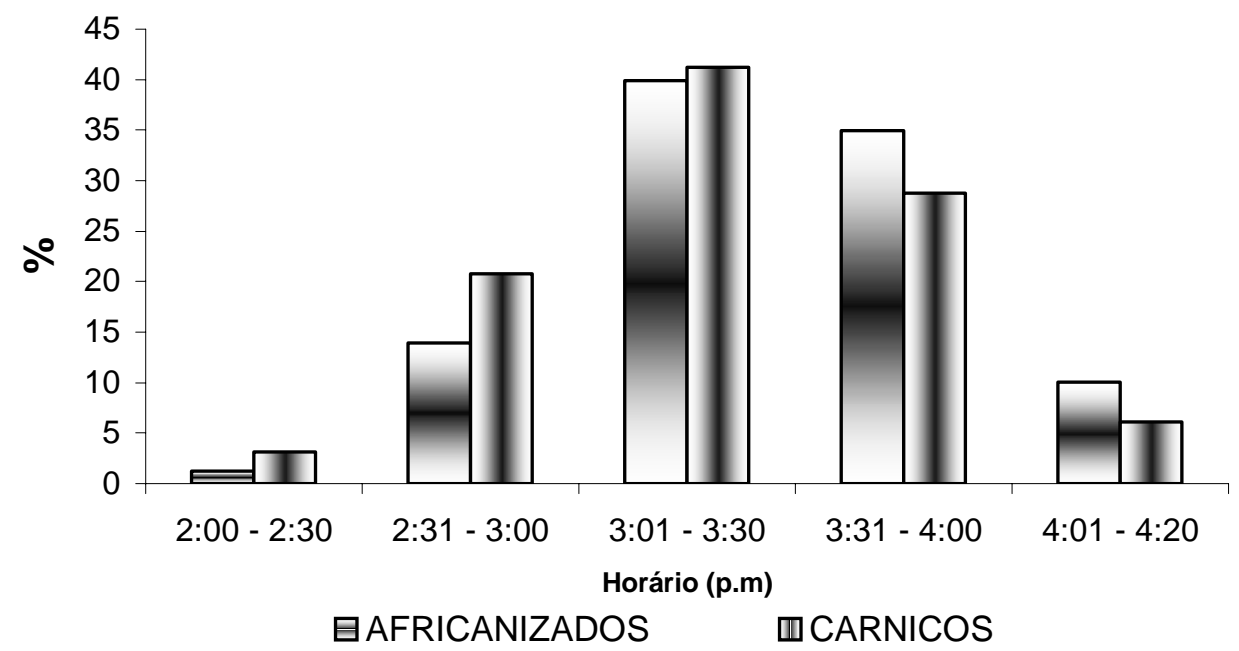

Figura 9 - Horário de pico de atividade de vôo dos zangões africanizados e carnicos. 


\subsection{ANÁLISES DAS ÁREAS DE CONGREGAÇÃO DE ZANGÕES}

Os locais considerados ACZ foram localizados dentro da área do campus da USP em Ribeirão Preto, podendo ser vistos na figura 10, com as seguintes descrições:

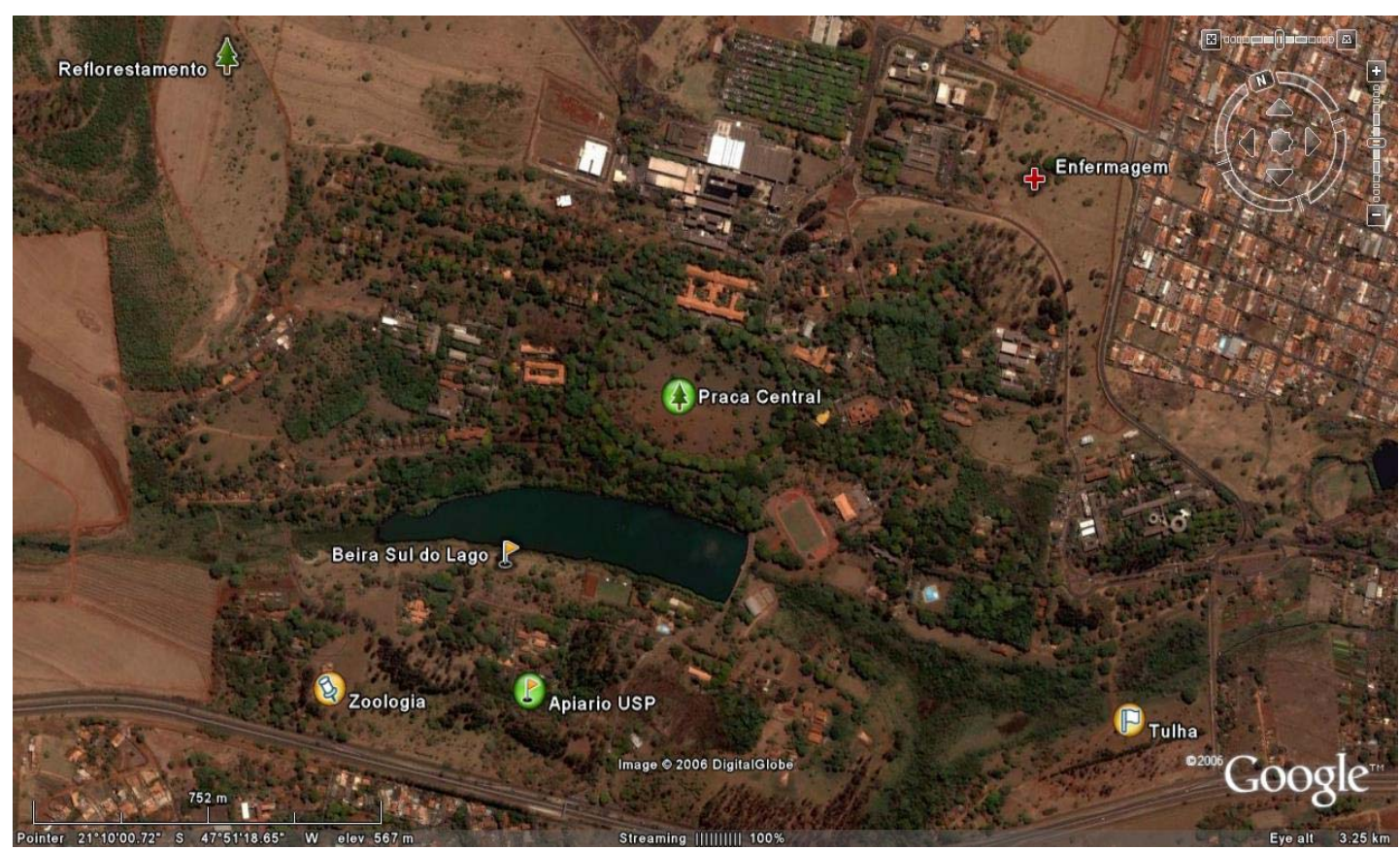

Figura 10 - Imagem de satélite do campus da USP de Ribeirão Preto e os locais onde foram analisadas as ACZ (Fonte: Google Earth).

- PRAÇA CENTRAL: Localizada em uma posição a nordeste do apiário experimental, a uma distância de 698 metros em linha reta e uma altitude de 568 metros.

- MARGEM SUL DO LAGO: Localizada em uma posição a norte do apiário experimental, a uma distância de 286 metros em linha reta e uma altitude de 561 metros.

- ZOOLOGIA: Localizada em uma posição a noroeste do apiário experimental, a uma distância de 443 metros em linha reta e uma altitude de 585 metros.

- REFLORESTAMENTO: Localizado em uma posição a norte do apiário experimental, a uma distância de 1470 metros em linha reta e uma altitude de 608 metros. 
- TULHA: Localizada em uma posição a suldeste do apiário experimental, a uma distância de 1342 metros em linha reta e uma altitude de 542 metros.

- ENFERMAGEM: Localizada em uma posição a nordeste do apiário experimental, a uma distância de 1531 metros em linha reta e uma altitude de 608 metros.

A dinâmica da presença dos zangões nas ACZ durante este experimento pode ser observada na figura 11. Verificou-se que a ACZ que apresentou uma maior presença de zangões foi a área do reflorestamento, seguida pelas áreas da enfermagem, zoologia, tulha e finalmente aquela localizada na praça central. O ponto "Margem sul do lago" não atraiu nenhum zangão à isca durante as observações. Porém, quando os números dos zangões nas diferentes ACZ foram analisados estatisticamente, verificou-se que, a análise de variância, não apresentou diferenças significativas entre as diferentes ACZ $(P=0,109)$. Também, observamos que existiu uma tendência por parte dos zangões a um pico de atividade no intervalo entre 15:00 e 16:00 horas. Somente em algumas áreas foram verificados poucos zangões durante o primeiro horário de observação às 14:00 h, não ultrapassando 5 zangões junto à isca.

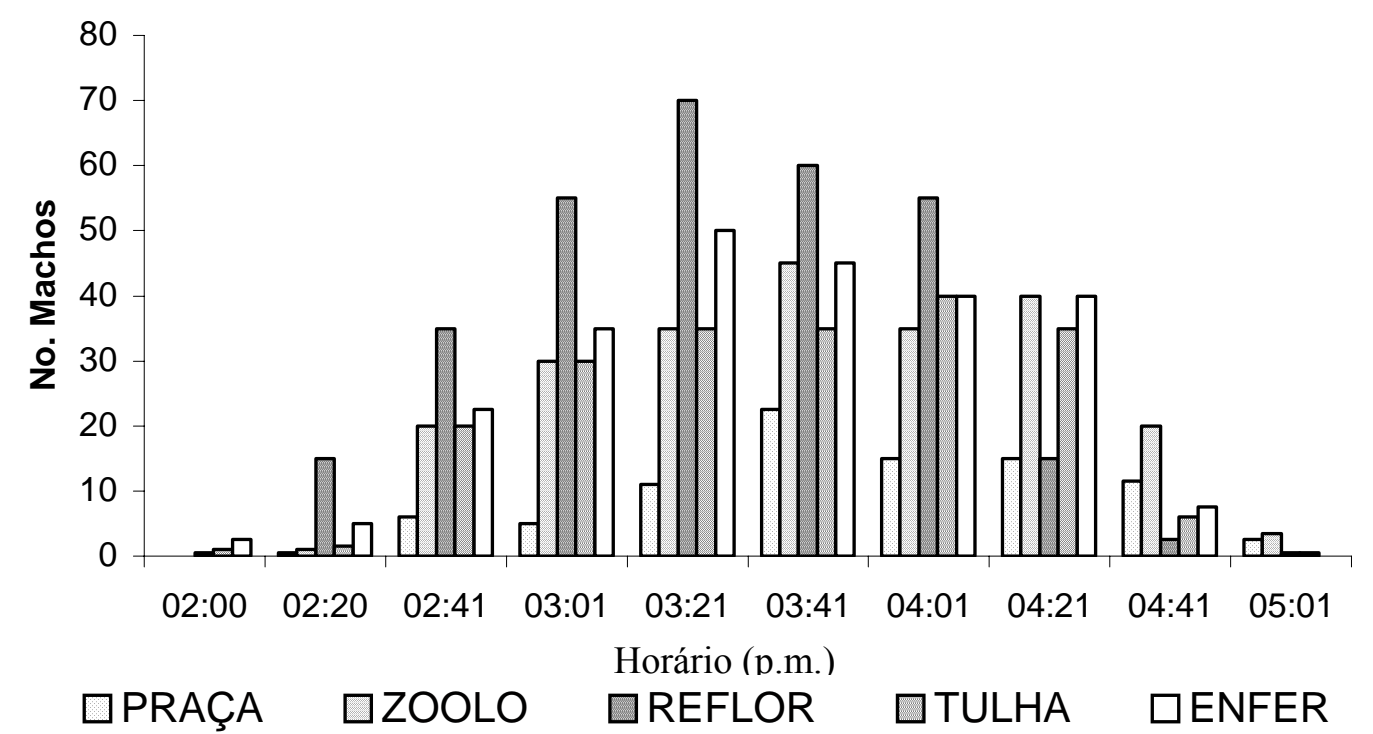

Figura 11 - Número médio de zangões observados seguindo a isca nas diferentes ACZ. 
Ao analisarmos estatisticamente a velocidade do vento $(\mathrm{m} / \mathrm{s})$, a análise de variância constatou diferenças significativas entre as diferentes $\mathrm{ACZ}(\mathrm{P}=<0,001)$. Pelo método de comparações múltiplas "Holm-Sidak" ocorreu diferenças significativas entre as seguintes ACZ: Praça central e Zoologia $(\mathrm{P}=<0,001)$; Reflorestamento e Zoologia ( $\mathrm{P}=<0,001)$; e Enfermagem e Zoologia $(\mathrm{P}=<0,001)$, não foram encontradas diferenças significativas entre as ACZ: Praça central e Tulha $(\mathrm{P}=0,0171)$; Tulha e Zoologia $(\mathrm{P}=0,0307)$; Reflorestamento e Tulha $(\mathrm{P}=0,116)$; Enfermagem e Tulha $(\mathrm{P}=0,147)$; Praça central e Enfermagem $(\mathrm{P}=0,323)$; Praça central e Reflorestamento $(\mathrm{P}=0,388)$ e finalmente entre o Reflorestamento e Enfermagem $(\mathrm{P}=0,899)$. Sendo que a ACZ da "Zoologia" foi a área que apresentou os ventos mais fracos.

No entanto, quando analisados os dados referentes à luminosidade, verificamos que não existem diferenças significativas entre as diferentes áreas $(\mathrm{P}=0,288)$.

Um dos objetivos a serem discutidos, neste trabalho, é se existiu alguma relação entre a velocidade do vento $(\mathrm{m} / \mathrm{s})$ e o número de zangões em cada uma das ACZ observadas. Desta forma foi análisado estatísticamente pela "Correlação de Pearson" os dados coletados para cada uma das ACZ, obtendo-se: Praça Central ( $r=$ -0,166; $\mathrm{P}>0,05)$; Zoologia ( $r=0,242 ; \mathrm{P}>0,05)$; Reflorestamento $(r=0,223 ; \mathrm{P}>0,05)$; Tulha $(r=-0,023 ; \mathrm{P}>0,05)$ e Enfermagem $(r=0,204 ; \mathrm{P}>0,05)$, não encontrando, em nenhuma destas áreas analisadas, uma correlação positiva $\geq 0,5$ (para detalhes, ver os gráficos da figura 12).

Também foi determinada a correlação entre o número de zangões e a luminosidade (X 100Lux). Esta análise revelou as seguintes correlações: Praça Central ( $r=-0,128 ; \mathrm{P}>0,05)$; Zoologia $(r=-0,200 ; \mathrm{P}>0,05)$; Reflorestamento $(r=$ 0,190; $\mathrm{P}>0,05)$; Tulha $(r=-0,033 ; \mathrm{P}>0,05)$ e Enfermagem $(r=-0,130 ; \mathrm{P}>0,05)$, não encontrando, para nenhuma destas áreas analisadas, uma correlação positiva $\geq 0,5$ (para detalhes, ver gráficos da figura 13). 


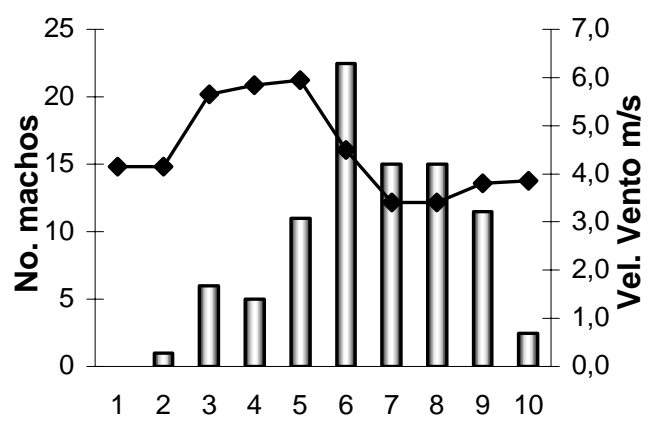

A. “Praça Central” $r=-0,166$

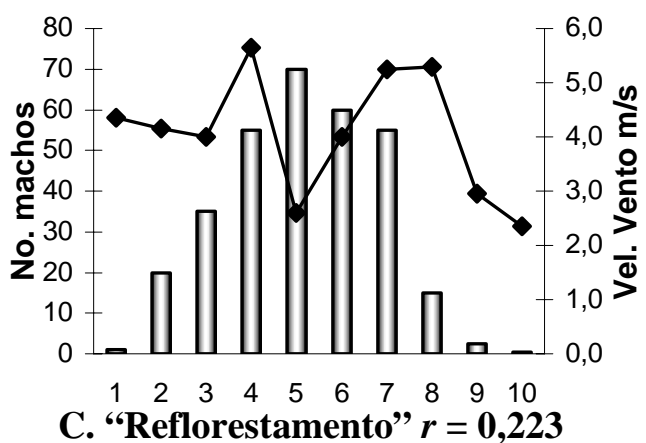

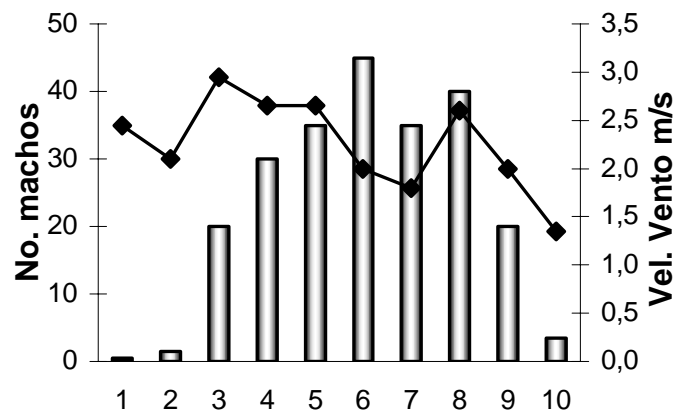

B. “Zoologia” $r=0,241$

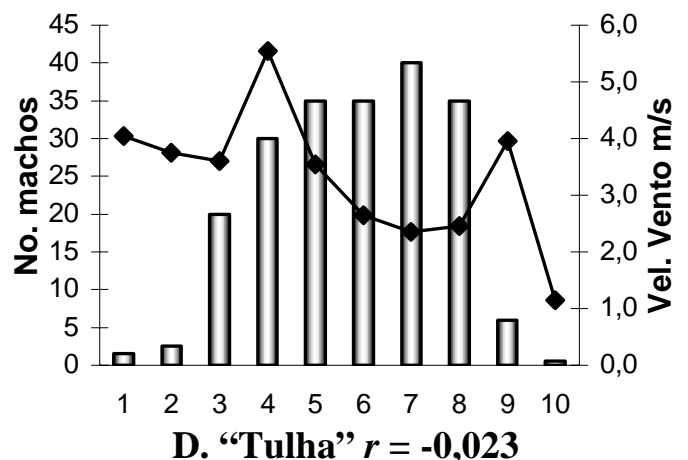

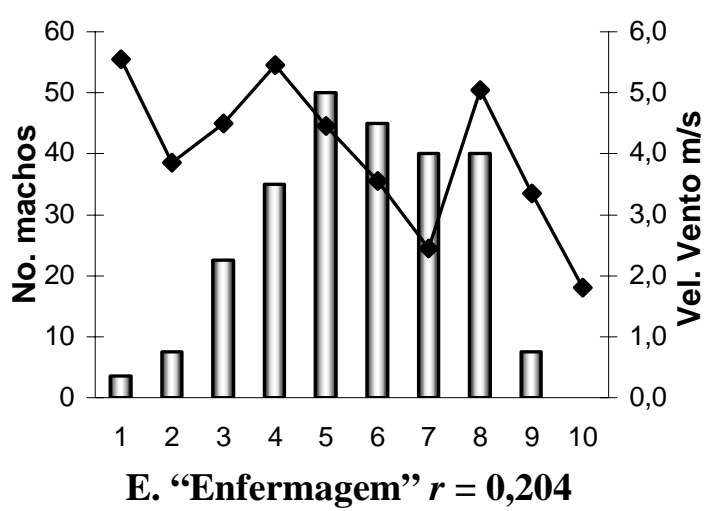

Figura 12 - Resultados obtidos nos diferentes pontos analisados, durante cada intervalo de observação (20 min.), iniciando às 14:00 h e terminando às 17:00 $\mathrm{h}$. As barras representam o número de zangões observados; as linhas indicam a velocidade do vento. As correlações destes parâmetros estão indicadas por “ $r$ ". 


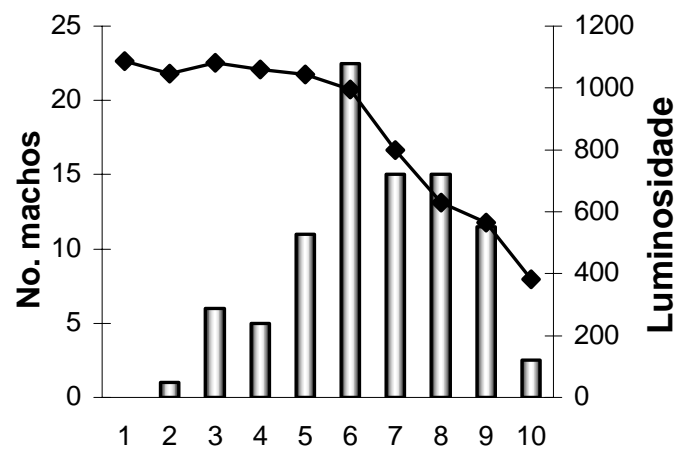

A. “Praça Central” $r=-0,128$

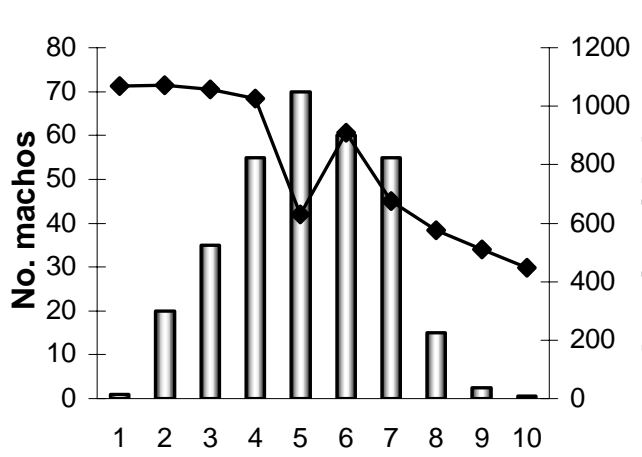

C. "Reflorestamento" $r=0,190$

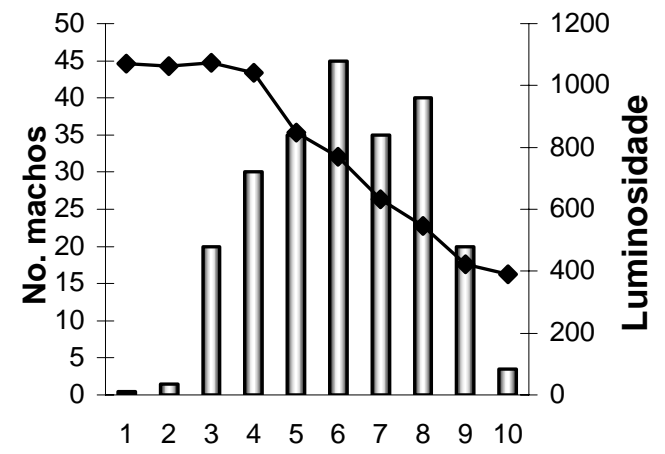

B. “Zoologia” $r=-0,200$

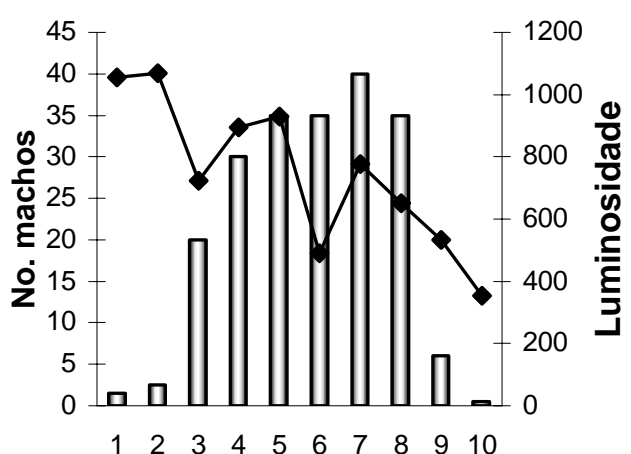

D. “Tulha” $r=-0,033$

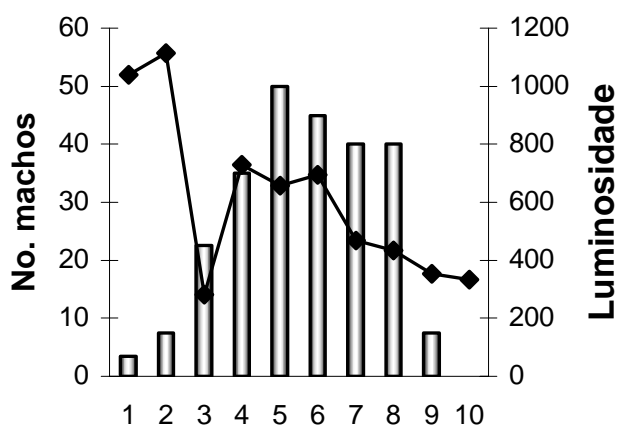

E. “Enfermagem” $r=-0,130$

Figura 13 - Resultados obtidos nos diferentes pontos analisados, durante cada intervalo de observação (20 min.), iniciando às 14:00 h e terminando às 17:00 h. As barras representam o número de zangões observados; as linhas indicam a Intensidade luminosa (X100 Lux). As correlações destes parâmetros estão indicadas por " $r$ ". 
A quantidade aproximada de zangões que perseguiram a isca foi determinada por meio de registros fotográficos, alguns destes registros podem ser vistos na figura 14, abaixo.

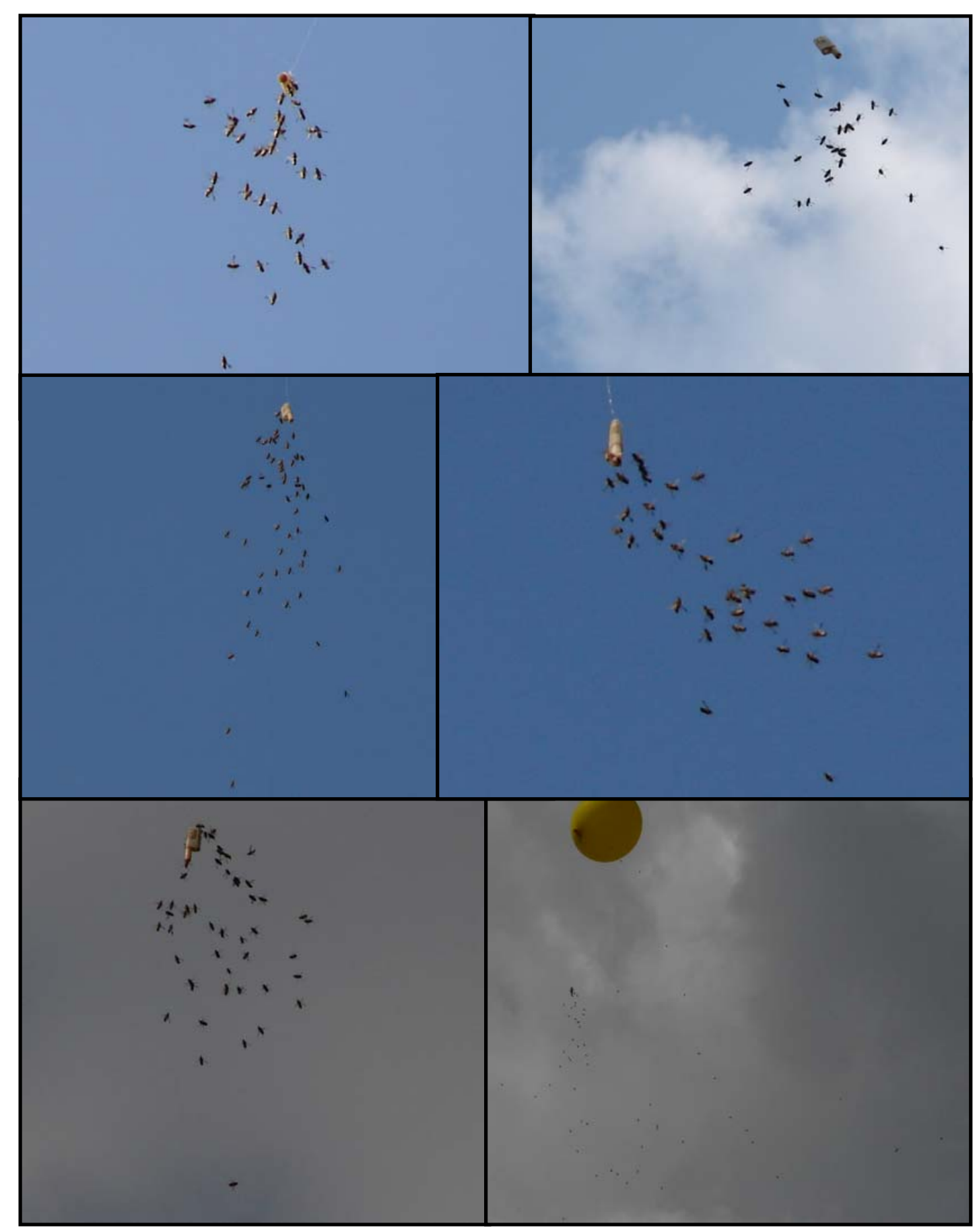

Figura 14 - Alguns registros fotográficos e imagens das diferentes áreas de congregação de zangões. 


\subsection{COLETA DE ZANGÕES NAS ACZ}

Durante todas as observações nas ACZ foram coletados zangões com o objetivo de verificar a presença dos zangões previamente marcados. No entanto não foi coletado nenhum dos zangões marcados em nenhuma das ACZ analisadas e monitoradas durante este trabalho. 


\section{DISCUSSÃO}

Alguns trabalhos sobre o comportamento de vôo de rainhas, como o de Teixeira (1992), no qual analisou o comportamento de vôo de rainhas africanizadas e rainhas italianas, revelando diferenças entre estas subespécies quanto ao horário do dia em que são realizados os vôos de acasalamento. Poderia-se concluir, a partir deste trabalho, que existiria algum tipo de comportamento específico para cada uma destas subespécies, constituindo-se ou não em algum tipo de barreira reprodutiva durante o acasalamento. Porém, pudemos constatar a partir de nossos experimentos, onde esta diferença não foi observada, que o comportamento de vôo destas subespécies, quanto ao horário do dia em que as rainhas realizam o vôo de acasalamento, foram similares. Estes dados diferem das conclusões feitas por Ruttner (1956), quem mencionou que há diferenças comportamentais no acasalamento das rainhas de diferentes raças de abelhas.

Teixeira (1992) mencionou que os zangões italianos apresentaram uma tendência a realizar seus vôos mais cedo entre 14:00 e 15:00 h do dia e que os zangões africanizados apresentaram um pico de atividade após os italianos, entre 15:00 e 16:00 h do dia. Porém os dados obtidos confirmaram o que foi observado por Cristino (2003), que mencionou não haver diferenças significativas no comportamento de vôo de zangões africanizados e italianos. Os dados de nosso experimento são semelhantes aos observados em 2003, não encontrando diferenças significativas entre zangões africanizados e carnicos. Podemos mencionar que os machos de abelhas italianas e carnicas não apresentaram nenhum tipo de comportamento específico de horário de vôo, fato este que possa beneficiar o 
acasalamento dos machos africanizados. Tendo em vista que os horários de vôos destas subespécies foram similares.

As ACZ são intensamente pesquisadas, devido ao fato de envolverem um local específico no qual ocorrem os acasalamentos entre rainhas e zangões. As pesquisas realizadas com ajuda de radar revelaram que os zangões realizaram vôos ao longo de áreas próximas a sua colméia, sendo realizados por rotas de vôo e que podem ser redirecionados em locais abertos, onde também estes indivíduos realizam vôos a uma maior altitude, ficam por um período maior de tempo. Estes locais, segundo Loper et al. (1992), são os locais considerados como ACZ.

De todos os pontos selecionados para serem considerados como ACZ, somente um destes pontos não apresentou zangões durante as observações. Podendose considerá-lo como um local que não faz parte das rotas de vôo e que mesmo que possua um espaço aberto típico de $\mathrm{ACZ}$, não apresentou atração aos vôos dos zangões.

Dados coletados, neste experimento, revelaram que os zangões freqüentam estas áreas durante condições de vento superiores a $4 \mathrm{~m} / \mathrm{s}$, e em algumas ocasiões com ventos à $8,1 \mathrm{~m} / \mathrm{s}(29,1 \mathrm{k} / \mathrm{h})$, como pode ser observado na $\mathrm{ACZ}$ denominada como Tulha. Neste ponto e sob essa velocidade de vento foram observados, aproximadamente, 30 zangões junto à isca.

Ventos fortes são considerados um fator limitante durante as observações nas ACZ, porém, não seja porque os zangões não realizem seus vôos de acasalamento e sim pelo fato da metodologia utilizada durante as observações. Ou seja, ventos fortes, na maioria dos casos, não permitem que o balão levante a rainha a uma altitude adequada, pois o vento forte exerce muita força, mantendo o balão rente ao chão.

Constatou-se que, durante o momento de usar a armadilha levantada pelo balão de Helio, alguns fatores como, por exemplo, a velocidade do vento, foi o parâmetro determinante no uso desta, já que os ventos fortes impediram o balão levantá-la, deixando-a próxima ao chão. Observou-se, em alguns momentos que os zangões não se aproximaram em igual número da isca, quando a armadilha estava anexada, diferentemente quando havia somente a isca junto ao balão. 
Foi observado, neste experimento, que os zangões realizaram seus vôos de acasalamento, mesmo em dias fechados e com pouca luminosidade.

Não foi possível associar os zangões previamente marcados às diferentes áreas estudadas. Como também foi desconhecido o número de colônias ou enxames silvestres que poderiam serem encontrados na área do campus da USP de Ribeirão Preto. A partir deste ponto de vista, a possibilidade de capturar algum macho previamente marcado em uma ACZ foi relativamente baixa. Tendo em vista que, uma única ACZ pode conter zangões provenientes de, aproximadamente, 238 colônias diferentes, como foi relatado por Baudry et al. (1998). Também devemos considerar, conjuntamente, que os zangões podem realizar mais de um vôo de acasalamento e que estes vôos poderiam ser realizados em diferentes rotas, porém, sem nenhuma preferência de direção, diminuindo a chances de captura destes indivíduos marcados.

As experiências práticas têm mostrado que na região de Ribeirão Preto é possível fecundar uma rainha em qualquer mês do ano, constatando, desta forma, que as ACZ se mantém ao longo do ano. Porém, é facilmente observado que as colônias africanizadas produzem zangões sob duas condições: Quando a colônia fica sem uma fêmea reprodutiva, e algumas operárias desenvolvem seus ovários, dando origem a uma colmeia "zanganeira"; ou quando as condições ambientais favorecem uma grande oferta de alimento, levando a um incremento no número de indivíduos, e assim, estimulando a produção de zangões. Segundo estas condições, podemos ter uma maior concentração de zangões africanizados em determinados meses do ano, facilitando, desta forma, os estudos sob o comportamento reprodutivo em ACZ. Em alguns meses do ano (durante o inverno), mesmo que existam zangões na ACZ, o número observado na área pode ser mínimo, dificultando o estudo durante estes meses.

Deve se ater para um erro na interpretação das $\mathrm{ACZ}$, quanto da existência de áreas fixas predeterminadas. Segundo este estudo, pode-se concluir que as áreas são locais abertos, que permitem aos zangões realizem vôos de reorientação e ao mesmo tempo permitem que o feromônio de uma rainha virgem seja facilmente difundido. 
Caso as ACZ fossem locais específicos, zangões provenientes de outras regiões teriam dificuldade em localizá-las. Porém, as ACZ são determinadas pela flora e estrutura do local. Espaços abertos permitem que os zangões voem por algum tempo, incrementando, desta forma, o número de zangões que possam permanecer nestes locais em um determinado período de tempo.

Não foi observado uma preferência dos zangões por determinada ACZ, além disto, como pode-se ver no campus e na maioria das regiões do Brasil, espaços abertos típicos de ACZ são facilmente encontrados no ambiente, oferecendo, desta forma, grande número de opções de vôo aos indivíduos.

A metodologia utilizada não permitiu confirmar todas as hipóteses levantadas, porém, facilitou a compreensão e melhorou o conhecimento dos locais onde as abelhas realizam seus vôos de acasalamento. Bem como as interações reprodutivas entre as diferentes subespécies de Apis mellifera durante o processo de Africanização. 


\section{CONCLUSÕES}

Para apreciar melhor a interação entre as abelhas africanizadas e as abelhas européias nas Américas e conseqüentemente o tipo de comportamento reprodutivo e a dinâmica dos cruzamentos, é muito importante ater-se a ecologia de seus reprodutivos. O comportamento das abelhas africanizadas responde, principalmente, a alguns destes fatores. Pode-se observar as vantagens adaptativas e as facilidades reprodutivas desta abelha em comparação a abelhas de origem européia. Isto é observado, principalmente, em paises tropicais, onde o comportamento das abelhas européias são menos adaptados a tais condições ambientais em comparação às abelhas africanizadas.

Abelhas africanizadas apresentam uma rápida taxa de crescimento, associada à facilidade em explorar novos nichos ecológicos, respondendo mais rapidamente na coleta de recursos. Estes e alguns outros fatores, como a enxameação, permitiu a rápida expansão destas abelhas para novas áreas, conquistando novos hábitates.

Acreditava-se que as ACZ foi um ponto determinante, que ajudaria a explicar um pouco melhor o processo de africanização, porém, como foi visto, o comportamento reprodutivo destas subespécies não apresentaram diferenças comportamentais, compartilhando, desta forma, das mesmas ACZ.

No entanto, podemos afirmar que colônias de abelhas africanizadas, devido a uma alta taxa de crescimento, um maior número de colônias naturais e uma superioridade numérica de zangões, conseguiram colonizar novas áreas, aumentando rapidamente o número de enxames e ao mesmo tempo diminuindo a contribuição genética por parte das abelhas européias, durante todos estes anos. 
Uma vez levantada a isca junto ao balão de Hélio, pôde-se ver rapidamente a atração dos zangões à isca nos pontos considerados como ACZ, aumentando em número e formando o cometa. O tempo que os zangões demoraram para localizar a rainha (isca) variou segundo a velocidade do vento, a área estudada e principalmente o período do ano. Durante este experimento foi observado a presença de zangões na isca praticamente de imediato, quando ela era levantada. Em alguns destes locais o tempo para o surgimento dos primeiros machos não ultrapassou os 60 segundos.

Os zangões freqüentam as ACZ, principalmente, durante o período da tarde, entre 14:00 e 17:00 horas, após este intervalo de tempo a quantidade de zangões observados tornou-se quase nula.

Neste experimento, não foi possível concordar com Koeniger et al. (2005b), que mencionou que os zangões têm preferência por $\mathrm{ACZ}$ que ficavam mais próximas do apiário. Como foi comentado anteriormente, a quantidade de colônias naturais que podem ser encontradas na área do campus da USP e próximo a este, são desconhecidas, contribuindo com zangões. Adicionalmente, os dados coletados durante todo este trabalho, não permitiram afirmar que os zangões observados nas cinco ACZ analisadas, foram originários do apiário experimental do Depto. de Genética, desconhecendo-se, assim, a origem e localização das colônias destes machos.

Do ponto de vista prático, acredita-se que, devido à seleção e às $\mathrm{ACZ}$, muitos apicultores poderiam ter problemas de consangüinidade. Este caso ocorreria em regiões onde o número de colmeias fosse relativamente pequeno e a pressão de seleção fosse alta. Porém, em paises que possuem abelhas africanizadas, a quantidade de enxames naturais é alta, sendo este risco de consangüinidade menor.

Teorias a cerca dos campos de fecundação de rainhas são constantemente discutidas, e é comum escutar apicultores mencionando que suas rainhas virgens acasalam em locais próximos a seus melhores apiários. Porém, não pode-se garantir um melhoramento genético sob estas condições, tendo em vista que se desconhece a origem dos zangões, podendo não serem filhos das melhores colmeias ali mantidas.

Atualmente existem muitas colônias na natureza e o número de enxames produzidos anualmente são desconhecidos, porém são considerados como muito 
freqüentes. Tal fato incrementa o número de colônias não manejadas e desconhecidas que poderiam estar visitando as ACZ e participando no acasalamento das rainhas. Determinar a origem dos machos em uma ACZ e ao mesmo tempo isolá-la, com o objetivo de realizar melhoramento genético, é um dos passos mais complicados a serem implementados na apicultura com abelhas africanizadas.

No entanto, um programa de melhoramento em massa em toda uma região, poderia aumentar o número de colônias manejadas e geneticamente selecionadas, o que poderia promover uma super oferta de zangões geneticamente selecionados na temporada reprodutiva. 


\section{REFERENCIAS BIBLIOGRÁFICAS}

BAUDRY, E., SOLIGNAC, M., GARNERY, L., GRIES, M., CORNUET, J. M. \& KOENIGER, N. Relatedness among honeybees (Apis mellifera) of drone congregation. Proc. R. Soc. Lond. v. 265, p. 2009-2014, 1998.

CLARKE, K. E., OLDROYD, B. P., QUEZADA-EUÁN, G \& RINDERER, T. E. Origin of honey bees (Apis mellifera L.) from the Yucatan peninsula inferred from mitochondrial DNA analysis. Mol Ecol. v. 10, n. 6, p. 1347-1355, 2001.

CLARKE, K. E., RINDERER, T. E., FRANK, P., QUEZADA-EUÁN, J. G \& OLDROYD, B. P. The africanization of honeybees (Apis mellifera L.) of the Yucatan: A study of a massive hybridization event across time. Evolution. v. 56, n. 7, p. 1462-1474, 2002.

CRISTINO, S. A. Aspectos reprodutivos envolvidos no processo de africanização das abelhas Apis mellifera no Brasil. Dissertação de Mestrado. FMRP-USP, Ribeirão Preto. 99p, 2003.

DEGRANDI-HOFFMAN, G., TARPY, D. R. \& SCHNEIDER, S. S. Patriline composition of worker populations in honey bee (Apis mellifera L.) colonies headed by queens inseminated with semen from African and European drones. Apidologie v. 34, p. 111-120. 2003.

DEGRANDI-HOFFMAN, G \& SCHNEIDER, S. S. Worker behaviors in queenless Africanized honey bee colonies. Proceedings of the $2^{\text {nd }}$ International Conference on Africanized Honey Bees and Bee Mites. Medina, OH: Root. p. 104-108, 2002.

DINIZ, N. M., SOARES, A. E. E., SHEPPARD, W. S \& DEL LAMA, M. A. Genetic structure of honeybee populations from southern Brazil and Uruguay. Genet. Mol. Biol. v. 26, p. 47-52. 2003.

DINIZ-FILHO, J. A. F \& MALASPINA, O. Evolution and population structure of Africanized honey bees in Brazil: Evidence from spatial analysis of morphometric data. Evolution. v. 49, n. 6, p. 1172-1179. 1995.

DOOLITLE, G. M; Mr. G. M.. Doolittle's queen rearing methods. Am. Bee J. v. 39, n. 28, p. 435-436, 1899.

ECHAZARRETA, C. M \& PAXTON, R. J. Comparative colony development of Africanized and European honey bees (Apis mellifera) in lowland Neotropical Yucatan, Mexico. J. Apic. Res. v. 36, p. 89-103. 1997. 
FRANCOY, T. M., WITTMANN, D., STEINHAGE, V., DRAUSCHKE, M., MÜLLER, S., GONÇALVES, L. S. \& DE JONG, D. Mophometrical changes in Africanized bees over time. Em publicação.

GARY, N. E. Chemical mating attractants in the queen honey bee. Science. v. 136, p. 773-774, 1962.

GARY, N. E. Obsertavions of mating behavior in the honey bee. J. Apic. Res. v. 2, p. 3-13, 1963.

GONÇALVES, L. S. The introduction of the African Bees (Apis mellifera scutellata) into Brazil and some comments on their spread in South America. Am. Bee J. v, 114. n, 11. p, 414, 415, 419. 1974.

GONÇALVES, L. S. Africanização das abelhas nas Américas, Impactos e perspectivas de Aproveitamento do Material genético. Anais do Encontro Brasileiro de Abelhas e Outros Insetos Sociais. Homenagem aos 70 anos de Warwick Estevam Kerr. Naturalia. Ed. Unesp. São Paulo. p, 126-134. 1992.

GONÇALVES, L. S. Africanized Honey Bee: Introduction, Adaptation and Benefits. In : International Apicultural Congress-Apimondia, 36. proceedings in Document Transformation Techonologies-CD. Durban-South Africa, Book of Abstracts. p. 32, 2001.

GONÇALVES, L. S. Impactos biológicos causados pela africanização das abelhas Apis mellifera e pela competição das abelhas africanas Apis mellifera scutellata com seu parasita social obrigatório, o pseudo clone da Apis mellifera capensis. In: SIMPÓSIO PROBLEMAS BIOLÓGICOS CAUSADORES DE IMPACTO NA APICULTURA 3. Ribeirão Preto - São Paulo, Brasil. Anais do V Encontro sobre Abelhas. p. 72-77, 2002.

GULER, A. \& ALPAY, H. Reproductive Characteristics of Some Honeybee (Apis mellifera L.) Genoty. J. Anim. Vet. Adv. v. 4, n. 10, p. 864-870. 2005

HALL, H. G. Genetic and physiological studies of African and European honey bee hybridizations: past, present and into the 21 st century. Apiculture for the 21 st Century. Cheshire, CT: Wicwas. P. 52-59, 1999.

HALL, H. G \& MURALIDHARAN, K. Evidence from mitochondrial DNA that African honey bees spread as continuous maternal lineages. Nature. v. 339, p. 211-213, 1989.

HALL, H. G \& SMITH, D. R. Distinguishing African and European honey bee matrilines using amplified mitochondrial DNA. Proc. Natl. Acad. Sci. USA. v. 88 , n. 10 , p. $4548-4552,1991$.

JEAN-PROST, P. Queen mating. In: Apimondia. XVIII Int. Beekeep. Congr. p. 404-408, 1958.

KERR,W.E., DE LEON DEL RIO, S \& BARRIONUEVO, M. D. The southern limits of the distribution of the Africanized honey bee in South America. Am. Bee. J. v. 122, p. 196-198. 1982.

KOENIGER, G. Reproduction and Mating Behavior. In RINDERER, T. E. (Ed.). Bee genetics and breeding. Orlando, Florida: Academic Press, Inc, p. 255-280, 1986. 
KOENIGER, G. Mating behavior of honey bees. In: NEEDHAM, G., PAGE, R., DELFINADO-BAKER, M \& BOWMAN, C. E. Africanized Honey Bees and Bee Mites. Ellis Horwood Limited. Chichester - England. p. 167-172. 1988.

KOENIGER, N \& KOENIGER, G. An evolutionary approach to mating behaviour and drone copulatory organs in Apis. Apidologie. v. 22, n. 6, p. 581-590, 1991.

KOENIGER, N \& KOENIGER, G. Reproductive isolation among species of the genus Apis. Apidologie. v. 31, n. 2, p. 313-339, 2000.

KOENIGER, N., KOENIGER, G,. GRIES, M \& TINGEK, S. Drone competition at drone congregation areas in four Apis species. Apidologie. v. 36, p. 211-221, 2005 a.

KOENIGER, N., KOENIGER, G \& PECHHACKER, H. The nearer the better? Drones (Apis mellifera) prefer nearer drone congregation areas. Insect. Soc. v. 52, n. 1, p. 31-35, 2005b.

KREBS, J. R e DAVIES, N. B. Introdução à Ecologia Comportamental. São Paulo: Atheneu Editora. p. 208-243, 1996.

LOPER, G. M., WOLF, W. W \& TAYLOR Jr, O. R. Detection and monitoring of honeybee drone congregation areas by radar. Apidologie. v 18, n 2, p 136-172, 1987.

LOPER, G. M., WOLF, W. W \& TAYLOR Jr, O. R. Honey bee drone flyways and congregation areas - radar observations. J Kansas Entomol Soc. v 65, n 3, p 223-230, 1992.

LOPER, G. M., WOLFAND, W. W \& TAYLOR Jr, O. R. Radar detection of drones responding to honeybee queen pheromone. Journal of Chemical Ecology. v 19, n 9, p 1929-1937, 1993.

LOPER, G. M. Nesting sites, characterization and longevity of feral honey bee colonies in the Sonoran desert of Arizona: 1991-2000. Proceedings of the $2^{\text {nd }}$ International Conference on Africanized Honey Bees and Bee Mites. Medina, OH: Root. p. 86-96, 2002.

MCNALLY, L. C \& SCHNEIDER, S.S. Seasonal cycles of growth, development and movement of the African honey-bee, Apis mellifera scutellata, in Africa. Insect. Soc. v. 39, n. 4, p. 167-179, 1992.

MISTRO, D. C, DÍAZ, L. A \& FERREIRA W. C. The Africanized honey bee dispersal: a mathematical zoom. Bulletin of Mathematical Biology. v. 67 281312. 2005.

NOGUEIRA-NETO, P. The beginning of beekeeping in Brazil. Boletim de Agricultura (Secretaria de Agricultura do Estado de São Paulo). p, 5-14. 1962.

NIELSEN, D. I., EBERT, P. R. PAGE Jr, R. E., HUNT, G. J \& GUZMÁN-NOVOA, E. Improved Polymerase Chain Reaction-Based Mitochondrial Genotype Assay for Identification of the Africanized Honey Bee (Hymenoptera: Apidae). Ann Entomol. Soc. Am. v. 93, n. 1, p. 1-6, 2000. 
OLDROYD, B. P., SMOLENSKI, A. J., CORNUET, J.M. \& CROZIER, R. H. Anarchy in the beehive. Nature. v. 371. p, 749. 1994.

OTIS, G. W., TAYLOR, O. R \& WINSTON, M. L. Colony size affects reproductive attributes of African honey bees (Apis mellifera L.) Proceedings of the $2^{\text {nd }}$ International Conference on Africanized Honey Bees and Bee Mites. Medina, OH: Root. p. 25-32, 2002.

OTIS, G. W. Population biology of the Africanized honey bee.The "African" Honey Bee. Boulder, CO: Westview. p. 213-234, 1991.

PAGE, R. E \& LAIDLAW, H. H. Honey bee genetics and breeding. In GRAHAM, J. M. The Hive and the Honey Bee. Hamilton, Illinois: Dadant \& Sons, Inc, p. 235-267, 1992.

PEER, D. F. Further studies on the mating range of the honey bee, Apis mellifera L. The Canadian Entomologist. v. 89, p. 108-110. 1957.

PINTO, M. A., RUBINK, W. L., PATTON, J. C., COUlSON, R. N. \&. JOHNSTON, J. S. Africanization in the United States: replacement of feral European honey bees (Apis mellifera L.) by an African hybrid swarm. Genetics. v. 170, p. 1653-1665 . 2005.

QUEZADA-EuÁN, J. J. G., ECHAZARRETA, C. M \& PAXTON, R. J. The distribution and range of expansion of Africanized honey bees (Apis mellifera) in the state of Yucatan, Mexico. J. Apicult. Res. v. 35, n. 3, p. 85-95, 1996.

QUEZADA-EUÁN, J. J. G \& PAXTON, R. J. Rapid intergenerational changes in morphology and behaviour in colonies of Africanized and European honey bees (Apis mellifera) from tropical Yucatan, Mexico. J. Apicult. Res. v. 38, n. 1, p. 93-104, 1999.

QUEZADA-EUÁN, J. J. G., MAY-ITZA, W. D. J. Partial seasonal isolation of African and European-derived Apis mellifera (Hymenoptera: Apidae) drones at congregation areas from subtropical Mexico. Ann. Entomol. Soc. Am. v. 94, n. 4, p. 540-544. 2001.

RATNIEKS, F. L. W. The evolution of polyandry by queens in social Hymenoptera: the signicance of the timing of removal of diploid males. Behav. Ecol. Sociobiol. v. 26. p, 343-348. 1990.

RINDERER, T. E., COLLINS, A. M., HELlMiCH, R. L \& DANKA, R. G. Differential drone production by Africanized and European honey-bees colonies. Apidologie. v. 18, n. 1, p. 61-67, 1987.

RINDERER, T. E. Africanized bees: the Africanization process and potential range in the United States. Bull. Entomol. Soc. Am. v. 32, p. 222-227. 1986.

RINDERER, T. E., HELLMICH, R. L., DANKA, R. G \& COLLINS, A. M. Male reprodutive parasitism: A factor in the Africanization of European honeybee populations. Science. v. 228, p. 1119-1121, 1985.

RINDERER, T. E \& HELLMICH, R. L. The processes of Africanation. In: SPIVAC, M., FLETCHER, D. J \& BREED, M. D. The “African" honey bee. San Fransisco. Westview Press. 5. p. 95-117. 1991. 
RUTTNER, F. The mating of the honeybee. Bee World. v. 37, n. 1, p. 3-15, 1956.

RUTTNER, F. The life and fligth activity of drones. Bee World. v. 47, p. 93-100, 1966.

RUTTNER, F.; RUTTNER, H. Untersuchungen über die Flugaktivität und das Paarungsverhalten der Drohnen. Apidologie. v. 3, n. 3, p. 203-232, 1972.

SCHLÜNS, H., MORITZ, R. F., NEUMANN, P., KRYGER, P \& KOENIGER, G. Multiple nuptial flights, sperm transfer and the evolution of extreme polyandry in honeybee queens. Anim. Behav. v, 70. p, 125-131. 2005.

SCHNEIDER, S. S., DEGRANDI-HOFFMAN, G \& SMINTH, D. R. The African honey bee: Factors contributing to successful biological invasion. Annu. Rev. Entomol. v. 49, p. 351-376, 2004.

SEGURA, J. A. L. Highly polymorphic DNA markers in an Africanized honey bee population in Costa Rica. Genet. Mol. Biol. v. 23, n. 2, p. 317-322, 2000.

SHEPPARD, W. S., SOARES, A. E. E., DE JONG, D \& SHIMANUKI, H. Hydrid status of honey-bee populations near the historic origin of Africanization in Brazil. Apidologie. v. 22, n. 6, p. 643-652 1991.

SNUSTAD, D. P \& SIMMONS, M. J. Fundamentos de Genética: A base cromossômica do Mendelismo. 2. ed. Rio de Janeiro. Guanabara Koogan S. A. p. 114. 2001.

SMITH, D. R., TAYLOR, O. R \& BROWN, W. M. Neotropical Africanized honey bees have African mitochondrial-DNA. Nature. v. 339, p. 213-215, 1989.

SUAZO, A., MCTIERNAN, R \& HALL, H. G. Differences between African and European honey bees (Apis mellifera L.) in random amplified polymorphic DNA (RAPD). J. Hered. v. 89, n. 1, p. 32-36, 1998.

SUGDEN, E. A., \& WILLIAMS, K. R. October 15: the day the bee arrived. Glean. Bee Cult. v. 119, p. 12-21. 1990.

TARPY, D. R \& PAGE, R. E. The curious promiscuity of queen honey bees (Apis mellifera): evolutionary and behavioral mechanisms. Ann. Zool. Fennici. v. 38, p. 255-265, 2001.

TAYLOR, O. R. Displacement of European honey bee subspecies by an invading African subspecies in the Americas. Apiculture for the 21 st Century. Cheshire, CT: Wicwas. p. 38-46, 1999.

TAYLOR, O. R. An aerial trap for collecting drone honeybees in congregation areas. J. Apicult. Res. v. 23, n. 1, p 18-20, 1984.

TAYLOR, O. R., Jr. African bees: potential impact in the United States. Bull. Entomol. Soc. Am. v. 31, p. 14-24. 1985.

TEIXEIRA, M. V. Aspectos comportamentais e fatores que influenciam na fecundação natural de rainhas de Apis mellifera (HYMENOPTERA: APIDAE), em região neotropical. Dissertação de Mestrado. FFCLRP-USP, Ribeirão Preto. 142p, 1992. 
TOZETTO, S. O. Hormonelle Steuerung in der Entwicklung von Drohnen (Apis mellifera carnica). Tese de Doutorado. Universität Tübingen, Alemanha. 122p, 1997.

VISSCHER, P. K., VETTER, R. S. \& BAPTISTA, F. C. Africanized bees, 19901995: initial rapid expansion has slowed in the U.S. Calif. Agric. v. 51, p. 2225. 1997.

WILLIAMS, J. L. Wind-directed pheromone trap for drone honey bees (Hymenoptera:Apidae). J. Econ. Entomol. v. 80, p. 532-536, 1987.

ZILLIKENS, A., SIMÕES, Z. L. P \& ENGELS, W. Higher fertility of queenless workers in the Africanized honey bee. Insect. Soc. v. 45, n. 4, p. 473-476, 1998.

ZMARLICKI, C.; MORSE, R. A. Drone congregation areas. Journal of Apicultural Research, v. 1, n. 2, p. 64-66, 1963. 


\begin{abstract}
AUTORIZAÇÃo
Autorizo a reprodução e/ou divulgação total ou parcial da presente obra, por qualquer meio convencional ou eletrônico, desde que citada a fonte.
\end{abstract}

OMAR ARVEY MARTÍNEZ CARANTÓN

UNIVERSIDADE DE SÃO PAULO

FACULDADE DE MEDICINA DE RIBEIRÃO PRETO

Av. DOS BANDEIRANTES 3900 - BLOCO “A”

omarapis@yahoo.com.br 